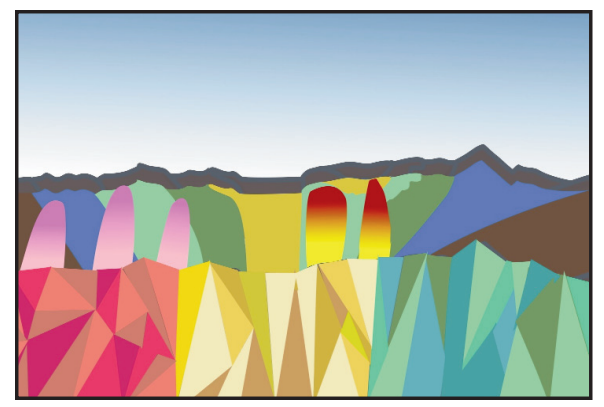

Arc and Slab-Failure Magmatism in Cordilleran Batholiths I - The Cretaceous Coastal Batholith of Peru and its Role in South American Orogenesis and Hemispheric Subduction Flip

\section{Robert S. Hildebrand ${ }^{1}$ and Joseph} B. Whalen ${ }^{2}$

'Department of Earth and Planetary Sciences

University of California, Davis, California 95616-8605, USA

E-mail:bob@roberthildebrand.com

${ }^{2}$ Geological Survey of Canada 601 Booth St., Ottawa, Ontario K1A 0E8, Canada

\section{SUMMARY}

We examined the temporal and spatial relations of rock units within the Western Cordillera of Peru where two Cretaceous basins, the Huarmey-Cañete and the West Peruvian Trough, were considered by previous workers to represent western and eastern parts respectively of the same marginal basin. The Huarmey-Cañete Trough, which sits on Mesoproterozoic basement of the Arequipa block, was filled with up to $9 \mathrm{~km}$ of Tithonian to Albian tholeiitic-calc-alkaline volcanic and volcaniclastic rocks. It shoaled to subaerial eastward. At 105-101 Ma the rocks were tightly folded and intruded during and just after the deformation by a suite of $103 \pm 2$ Ma mafic intrusions, and later in the interval 94-82 Ma by probable subduction-related plutons of the Coastal batholith. The West Peruvian Trough, which sits on Paleozoic metamorphic basement, comprised a west-facing siliciclasticcarbonate platform and adjacent basin filled with up to $5 \mathrm{~km}$ of sandstone, shale, marl and thinly bedded limestone deposited continuously throughout the Cretaceous. Rocks of the West Peruvian Trough were detached from their basement, folded and thrust eastward during the Late Cretaceous-Early Tertiary. Because the facies and facing directions of the two basins are incompatible, and their development and subjacent basements also distinct, the two basins could not have developed adjacent to one another.

Based on thickness, composition and magmatic style, we interpret the magmatism of the HuarmeyCañete Trough to represent a magmatic arc that shut down at about $105 \mathrm{Ma}$ when the arc collided with an unknown terrane. We relate subsequent magmatism of the early $103 \pm 2 \mathrm{Ma}$ syntectonic mafic intrusions and dyke swarms to slab failure. The HuarmeyCañete-Coastal batholithic block and its Mesoproterozoic basement remained offshore until $77 \pm 5 \mathrm{Ma}$ when it collided with, and was emplaced upon, the partially subducted western margin of South America to form the east-vergent Marañon fold-thrust belt. A major pulse of 73-62 Ma plutonism and dyke emplacement followed terminal collision and is interpreted to have been related to slab failure of the west-dipping South American lithosphere. Magmatism, $53 \mathrm{Ma}$ and younger, followed terminal collision and was generated by eastward subduction of Pacific oceanic lithosphere beneath South America. Similar spatial and temporal relations exist over the length of both Americas and represent the terminal collision of an arc-bearing ribbon continent with the Americas during the Late Cretaceous-Early Tertiary Laramide event. It thus separated longstanding westward subduction from the younger period of eastward subduction characteristic of today. We speculate that the Cordilleran Ribbon Continent formed during the Mesozoic over a major zone of downwelling between Tuzo and Jason along the boundary of Panthalassic and Pacific oceanic plates.

\section{SOMMAIRE}

Nous avons étudié les relations spatiales et temporales des unités de roches dans la portion ouest de la Cordillère du Pérou, où deux bassins crétacés, la fosse d'accumulation de Huarmey-Cañete et la fosse d'accumulation péruvienne de l'ouest, ont été perçues par des auteurs précédents comme les portions ouest et est d'un même bassin de marge. La fosse de 
Huarmey-Cañete, qui repose sur le socle mésoprotérozoïque du bloc d'Arequipa, a été comblée par des couches de roches volcaniques tholéitiques - calco-alcalines de l'Albien au Thithonien atteignant $9 \mathrm{~km}$ d'épaisseur. Vers l'est, l'ensemble a fini par former des hauts fonds. Vers 105 à $101 \mathrm{Ma}$, les roches ont été plissées fortement puis recoupées par une suite d'intrusions vers $103 \pm 2 \mathrm{Ma}$, durant et juste après la déformation, et plus tard dans l'intervalle 94 - $82 \mathrm{Ma}$, probablement par des plutons de subduction du batholite côtier. Quant à la fosse d'accumulation péruvienne de l'ouest, elle repose sur un socle métamorphique paléozoïque, et elle est constituée d'une plateforme silicoclastique - carbonate à pente ouest et d'un bassin contigu comblé par des grès, des schistes, des marnes et des calcaires finement laminés atteignant $5 \mathrm{~km}$ d'épaisseur et qui se sont déposés en continu durant tout le Crétacé. Les roches de la fosse d'accumulation péruvienne de l'ouest ont été décollées de leur socle, plissées et charriées vers l'est durant la fin du Crétacé et le début du Tertiaire. Parce que les facies et les profondeurs de sédimentation de ces deux fosses d'accumulation dont incompatibles, et que leur développement et leur socle sont différents, ces deux fosses ne peuvent pas s'être développées côte à côte.

À cause de l'épaisseur accumulée, de sa composition et du style de son magmatisme, nous pensons que la fosse d'accumulation de HuarmeyCañete représente un arc magmatique qui s'est éteinte vers $105 \mathrm{Ma}$, lorsque l'arc est entré en collision avec un terrane inconnu. Nous pensons que le magmatisme subséquent aux premières intrusions mafiques syntectoniques et aux réseaux de dykes de $103 \pm 2 \mathrm{Ma}$ sont à mettre au compte d'une rupture de plaque. Le bloc Huarmey-Cañetebatholitique côtier et son socle mésoprotérozoïque sont demeurés au large jusqu'à $77 \pm 5 \mathrm{Ma}$, moment où il est entré en collision et a été poussé pardessus la marge ouest sud-américaine partiellement subduite, pour ainsi former la zone de chevauchement de vergence est de Marañon. Nous croyons que la séquence majeure de plutonisme et d'intrusion de dykes qui a succédé à la collision finale à 73-62 Ma doit être reliée à une rupture de la plaque lithosphérique sud-américaine à pendage ouest. Le magmatisme de 53 Ma et plus récent qui a succédé à la collision finale, a été généré par la subduction vers l'est de la lithosphère océanique du Pacifique sous l'Amérique du Sud.

Des relations temporelles et spatiales similaires qui existent tout le long des deux Amériques représentent la collision terminale d'un ruban continental d'arcs avec les Amériques durant la phase tectonique laramienne de la fin du Crétacé-début du Tertiaire. Elle a donc séparé la subduction vers l'ouest de longue date de la période de subduction vers l'est plus jeune caractérisant la situation actuelle. Nous considérons que le ruban continental de la Cordillère s'est constitué durant le Mésozoïque au-dessus d'une zone majeure de convection descendante entre Tuzo et Jason, le long de la limite entre les plaques océaniques Panthalassique et Pacifique.

\section{INTRODUCTION}

In the 1972 discussion of the now classic paper, The Coastal batholith of Peru, Robert M. Shackleton, student of African geology and Royal Fellow, asked the authors why the granitic and related plutonic rocks of the batholith rose along a narrowly restricted zone over a long period of time (Cobbing and Pitcher 1972a). Because the plutons were undated at that time, Pitcher couldn't answer the question, but he did say that such a finding was indeed surprising. To this day Shackleton's query remains unanswered, and given the plethora of published papers on arc migration due to slab flattening and rollback over the past couple of decades, the question remains on point: Why was magmatism of the Coastal batholith (Figure 1), which we now know represents more than 40 m.y. of intense magmatism, confined to such a narrow band?

Over the four decades since, the Andes have become the standard example of an orogenic belt formed at a subducting plate margin, and so form a template for the interpretation of other orogenic belts. In the current paradigm, from the Gulf of Guayaquil southward, a long-lived arc complex formed within and upon the continental lip above the eastward-dipping sub- duction zone (Pitcher 1993; Jaillard and Soler 1996). In this hypothesis, while subduction remained easterly at least since the Jurassic, variable stresses within the margin, generally attributed to changes in slab dip and obliquity, led to arc migration and shut-down as well as periods of extension, which formed basins, and periods of compression, which created fold-thrust belts (for example Kay and Mpodozis 2002; Ramos and Folguera 2005; Ramos and Kay 2006; Mosquera and Ramos 2006; Ramos 2009, 2010a).

Because the Andes have long served as a living proxy for understanding the geology of the North American Cordillera (Hamilton 1969a, b; DeCelles et al. 2009), and because some researchers have recently challenged the idea of long-lived easterly subduction beneath North America (Moores et al. 2002, 2006; Johnston 2008; Hildebrand 2009, 2013), we decided to undertake a careful reexamination of existing data for western South America to better understand the analogs. In this contribution we focus on the Peruvian sector of the margin (Figure 1) where intrusions of the Coastal batholith constitute an immense, dominantly Late Cretaceous batholith, built mostly of tonalitic and granodioritic plutons that collectively form a linear $60 \mathrm{~km}$-wide band extending over $2000 \mathrm{~km}$ within the core of the Western Cordillera (Pitcher 1978, $1985,1993)$. Since the landmark publications of Cobbing and Pitcher, the batholith has been interpreted to be the direct result of long-lived eastward subduction of oceanic lithosphere beneath the South American continental margin (Pitcher 1978; Cobbing et al. 1981; Pitcher et al. 1985). Here we revisit the batholith and its setting to suggest an alternative explanation for its origin, which we believe finally answers the question Shackleton posed some 40 years ago. We end by briefly discussing how our new model affects the existing paradigm for Andean and hemispheric orogenesis.

\section{REGIONAL SETTING}

The Coastal batholith of Peru outcrops within the Cordillera Occidental, a range of towering peaks rising parallel to the Pacific coast and separated from it by a narrow desert plain, some 


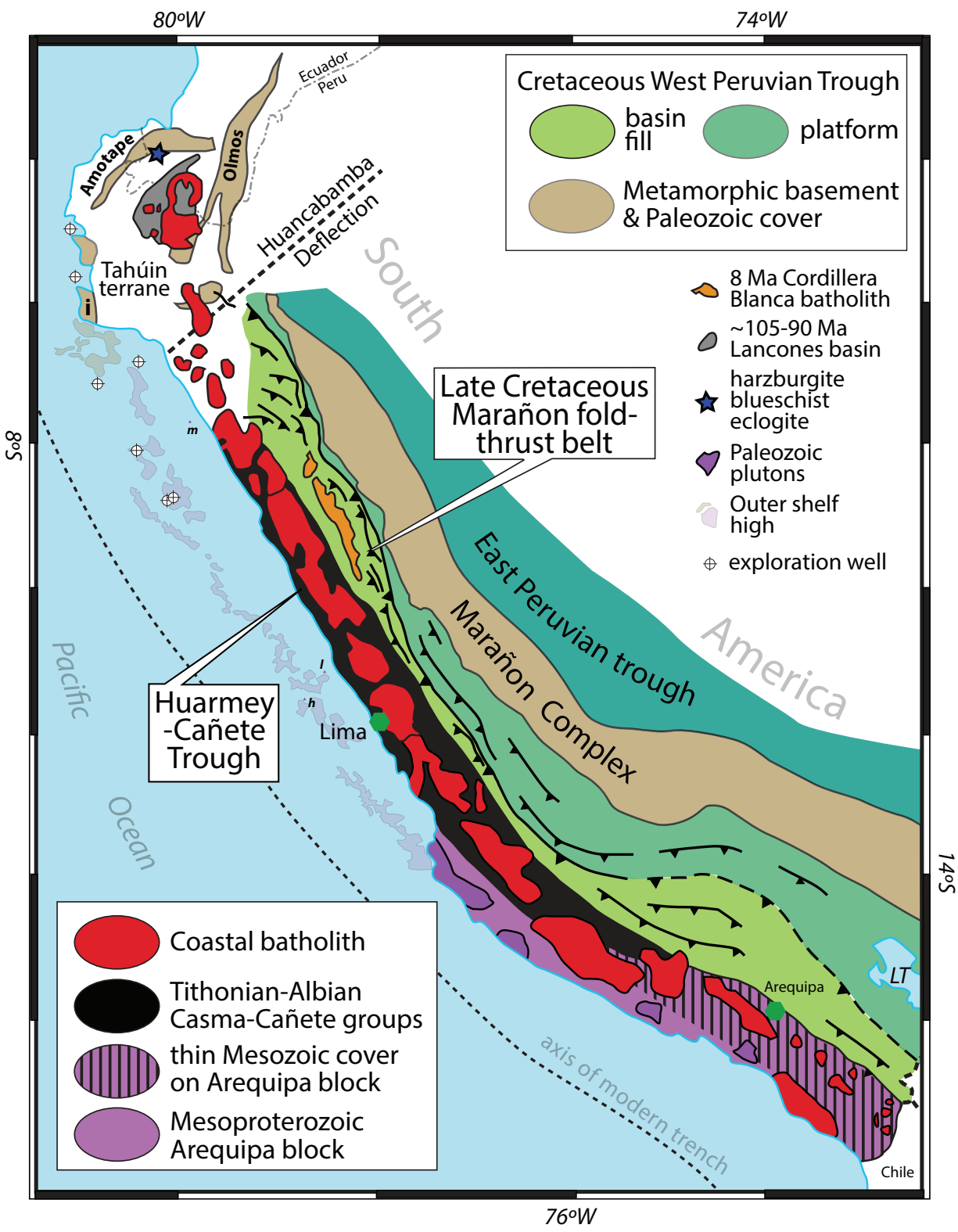

Figure 1. Geological sketch map of western Peru illustrating the general relations between Tithonian-Albian rocks of the Casma Group deposited in Huarmey basin, the Coastal batholith, and the West Peruvian Trough. Location of the Early Cretaceous subduction complex (harzburgite-blueschist-eclogite), which predated the events in this paper as the rocks there were exhumed during the Early Cretaceous, is from Feininger (1980). i-Illascas massif; $m$-Isla Macabi; $h-I$ sla de las Hormigas de Afuera; - -Isla Lobera; LT-Lake Titicaca.

15-150 km wide. To the northeast sits high plateau country and the Cordilleras Central and Oriental, which merge southward with the Cordillera Occidental in central Peru. Deep canyons dissect the ranges and provide excellent cross-sections of the geology, whereas the high plateau has a gently rolling topography. To the east of the Andes lies the jungle-covered, but apparently oil-rich, Amazon basin.

Emerging from the jungles of the Amazon are rocks of the Subandean region, an area of Tertiary basins overlying thick sequences of Phanerozoic rocks and basement, which to the west become progressively involved in thick-skinned basement-involved thrusts and thin-skinned thrusts (Mathalone and Montoya 1995; Pfiffner and Gonzalez 2013). Farther southwest, in the Cordillera Oriental, lies the Marañon complex (Figure 1), which is a northwest-trending belt of Late Neo- proterozoic to Paleozoic metamorphic rocks, including $\sim 600 \mathrm{Ma}$ orthogneiss, cut by Ordovician plutons, interpreted to represent part of a magmatic arc (Chew et al. 2007), and overlain by two sequences of metamorphosed Paleozoic rocks: an older sequence deposited and metamorphosed between 450 and $420 \mathrm{Ma}$; and a younger sequence deposited after $320 \mathrm{Ma}$ and metamorphosed at $310 \mathrm{Ma}$ (Cardona et al. 2009). A $300 \mathrm{~km}$-long discontinuous band of dismembered and serpentinized Neoproterozoic ophiolite buried to pressures of $12.5 \pm 1 \mathrm{kbar}$ and metamorphosed during the Ordovician, thrust over much less deformed and lower grade Carboniferous metasedimentary rocks, and preserved in part as klippen - outcrops in the western part of the complex (Castroviejo et al. 2009, 2010; Willner et al. 2010; Tassanari et al. 2011). There are also extensive tracts of Carboniferous and Permo-Triassic plutonic rocks (Chew et al. 2007; Mišković et al. 2009).

To the southwest are sedimentary rocks of the Late Jurassic-Cretaceous West Peruvian Trough (Wilson 1963). The trough (Figure 1), developed upon rocks of the Marañon complex, comprises an eastward-tapering wedge of marine sedimentary rocks with a west-facing sandstone and carbonate-dominated shelf - disconformably capped by latest Cretaceous to Paleocene, red, cross-bedded sandstone derived from the southwest- and a thicker sandstone-shale-limestone basinal facies to the southwest (Scherrenberg et al. 2012). In the traditional interpretation, the westernmost parts of the trough contain several interconnected subbasins such as the Huarmey in the north and Rio Cañete to the south, both of which were filled with 5000-9000 m of Cretaceous, dominantly Albian, submarine basaltic, andesitic, and dacitic volcanic rocks, collectively referred to as the Casma Group (Cobbing 1976, 1978, 1985). The main difference between the two subbasins is that in the Rio Cañete Basin to the south is a thick section of Early Cretaceous sedimentary rocks that predate the volcanic rocks, otherwise the basins were stratigraphically and structurally continuous and could be considered one basin (Cobbing 
1978). These westernmost subbasins are generally interpreted to be part of a single marginal basin that encompassed all of the West Peruvian Trough (Atherton et al. 1985a). The boundary between the eastern, sedimentary part of the basin and the western volcanic-dominated sequence has long been known to be abrupt. In his broad reconnaissance, Wilson (1963) called the change rapid; but in his subsequent work (Wilson et al. 1967), he realized that it was a faulted contact. Cobbing (1976) recognized that not only stratigraphy, but also structures within the two sectors were different, and so termed the eastern part a miogeosyncline and the western volcanic facies as eugeosynclinal. Myers $(1974,1975)$ described the boundary between the two as a tectonic line, which he named the Tapacocha Axis. Cobbing (1978), while recognizing the importance of the Tapacocha Axis, considered a more eastward fault, the Cordillera Blanca fault, as the critical tectonic line, because he thought that the Tapacocha Axis wasn't a persistent structure to both north and south.

The rocks of the HuarmeyCañete basins were intruded by the Coastal batholith (Figure 1), which ranges in age from $105 \mathrm{Ma}$ to $62 \mathrm{Ma}$ (Mukasa 1986). It is one of the great Cordilleran-type batholiths of the world and has been extensively studied by a British group headed by Pitcher and Cobbing (Cobbing and Pitcher 1972a, b; Cobbing et al. 1981; Cobbing and Pitcher 1983; Pitcher et al. 1985). The basement for the Haurmey-Cañete Trough and the Coastal batholith in the south is the Mesoproterozoic Arequipa terrane (Shackleton et al. 1979; Loewy et al. 2004; Casquet et al. 2010), whereas to the north, basement is unknown on-land as the Arequipa block strikes into the Pacific Ocean; however, recent exploration wells and studies of sparse offshore islands (Figure 1) discovered that the Arequipa block continues northward on the outer shelf high (Romero et al. 2013).

Rocks of the West Peruvian Trough were detached from their basement, folded, and thrust eastward during the Late Cretaceous and Early Paleocene, coincident with inversion of the basin and development of a widespread foredeep sequence preserved in

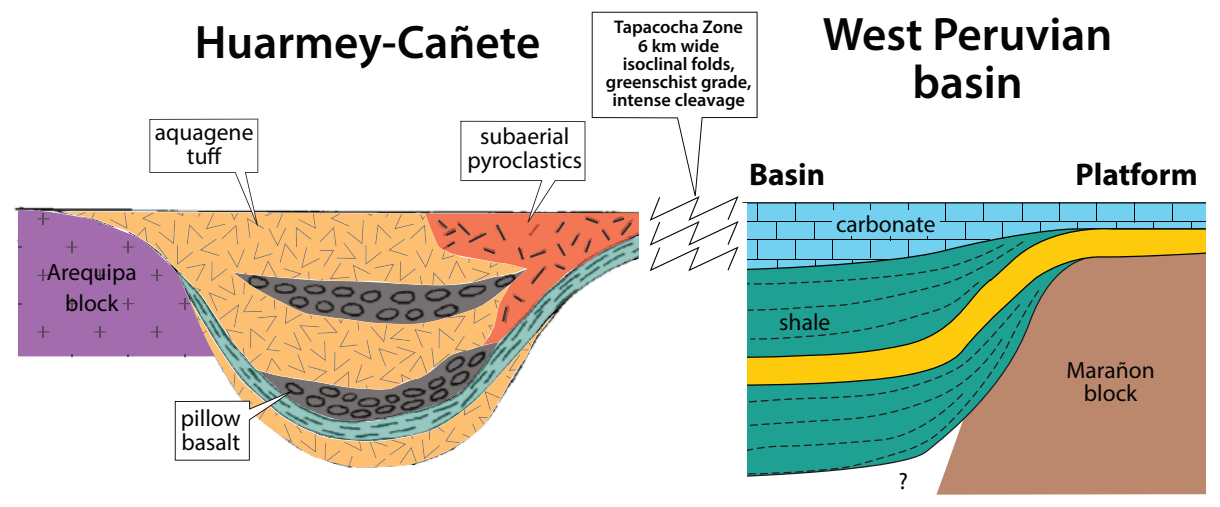

Figure 2. Schematic cross-section showing the commonly accepted relations within the West Peruvian-Huarmey marginal basin (modified from Cobbing 1976). We have added the Topacocha zone from Myers (1974).

part as the shallowing-upward marine to nonmarine Casapalca Formation, which sits disconformably on the older stratigraphic units (Scherrenberg et al. 2012). Paleocene and younger, broadly folded, terrestrial, intermediate to siliceous lavas and tuffs, along with related volcaniclastic rocks of the Calipuy Group sit disconformably atop rocks of the fold-thrust belt, the batholith, and its wall rocks (Atherton et al. 1985b; Figure 18 of Pfiffner and Gonzalez 2013).

\section{The Batholithic Envelope}

The main bulk of the Coastal batholith (Figure 1) was emplaced between about $100 \mathrm{Ma}$ and $60 \mathrm{Ma}$ into 5-9 km of volcanic and volcaniclastic rocks of the Casma Group, which are generally hypothesized to have been deposited within the actively subsiding, interconnected, linear basins of the HuarmeyCañete Trough (Cobbing 1978; Atherton et al. 1985a; Pitcher 1993). The age of the bedded rocks ranges from Tithonian to Albian, but the bulk of the section was erupted and deposited rapidly during the Latest Aptian and Albian (Myers 1974; Cobbing 1976; Atherton et al. 1983, 1985a; de Haller et al. 2006). Magmatism apparently ceased coincidentally with a period of deformation in the Late Albian (Atherton et al. 1985a; Atherton and Webb 1989).

Within the western part of the basin (Figure 2), several $2 \mathrm{~km}$-thick sections of tholeiitic basalt and associated hyaloclastite, along with massive andesitic lava piles, up to $1.8 \mathrm{~km}$ thick, are intercalated with aquagene tuff and associated sedimentary rocks, whereas to the east calc-alkaline andesitic to dacitic lavas, subaerial cooling units of ignimbrite, and lesser quantities of clastic sedimentary rocks dominate the sections (Myers 1974, Cobbing 1976; Atherton et al. 1985a). The facies indicate that the basin shoaled eastward.

As stated earlier, the

Huarmey-Cañete basin was considered to be the western part of a larger marginal basin, known as the West Peruvian Trough or basin (Figure 2), located to the east where it is entirely sedimentary and developed along the western side of a Paleozoic basement block known as the Marañon complex (Wilson 1963; Mégard 1987; Cardona et al. 2009). Rocks within the basin are sandstone, shale, limestone and marl that were deposited continuously from the Late Jurassic to the Late Cretaceous (Mégard 1984; Scherrenberg et al. 2012). Sedimentary rocks within the basin formed an eastward-tapering wedge and are divided into a thin, eastern platformal succession and a thick western sequence separated by a westside down, syn-sedimentary fault known as the Chonta fault (Scherrenberg et al. 2012). The western edge of the westward-deepening basin is abruptly truncated - and separated from rocks of the Huarmey-Cañete basin - by an obscure and mostly covered zone, in many places also invaded and obliterated by plutons, known as the Tapacocha Axis (Figure 2), a > 6 

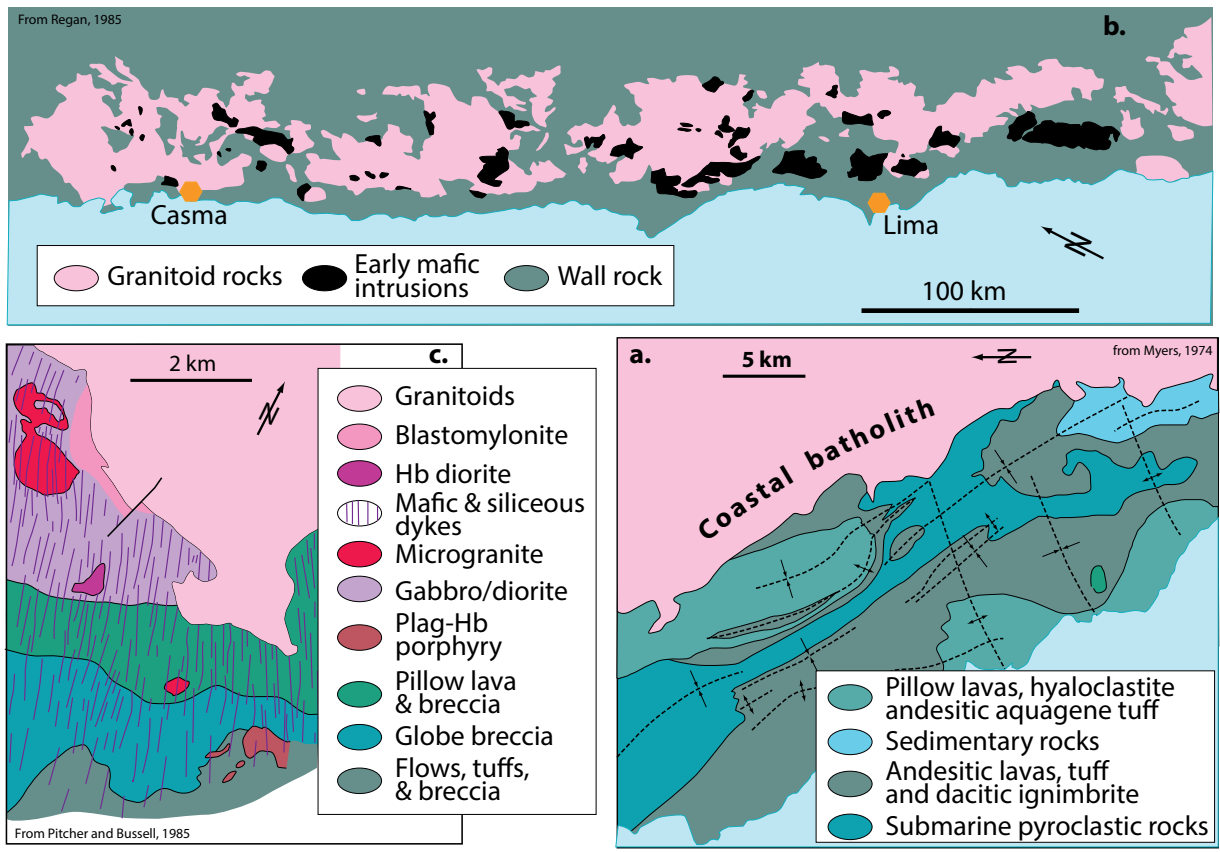

Figure 3. (a) Geological sketch map modified from Myers (1974) illustrating the two generations of folds that appear to predate the emplacement of the Coastal batholith; (b) sketch map from Regan (1985) showing the distribution of the early tholeiitic mafic intrusions; (c) geological map showing one area of a batholith-parallel dyke swarm related to the early mafic intrusions (modified from Pitcher and Bussell 1985).

$\mathrm{km}$ wide belt of isoclinal folds, greenschist-facies metamorphism, and intense cleavage development (Myers 1974).

Magmatism within the Huarmey-Cañete basins stopped during the late Albian and the rocks were variably folded, in places isoclinally (Figure 3a). Myers (1974) described two orthogonal fold sets: NNW, parallel to the basinal axes, and NE, normal to them (Figure 3a). Both sets plunge gently. The NNW set of folds is locally isoclinal, verges $\mathrm{NE}$, is in places overturned, and has acicular hornblende porphyroblasts aligned with fold axes. Myers used deformed ammonites to show that even gently dipping beds had in excess of $20 \%$ shortening. The ages of both sets of folds are tightly constrained as they postdate the main phase of Albian magmatism but predate a suite of mafic intrusions, dated at about 105-101 Ma (Mukasa 1986).

The sedimentary facies east of the Tapacocha belt within the West Peruvian Trough show neither evidence of this deformation nor an influx of immature sediment until the Late Cretaceous-Paleocene when fluvio-deltaic sediment, shed from the west, was deposited. At least $600 \mathrm{~m}$ of subaerial andesitic to basaltic lava and pyroclastic rocks sit unconformably upon the folded rocks (Myers 1974; Atherton et al. 1985a; Atherton and Webb 1989). The post-folding volcanic rocks thicken westward, are likely 100-82 Ma, and contain clasts of granite and porphyry not known from prefolding rocks (Atherton et al. 1985a).

\section{The Early Mafic Intrusions}

Rocks of the Huarmey-Cañete basin are riddled with a diverse suite of 105-101 Ma magnesian, calcic to calc-alkaline mafic intrusions (Figure 3b), dominantly peridotite, gabbro and diorite, which collectively comprise about $16 \%$ of the Coastal batholith (McCourt 1981; Regan 1985; Mukasa 1986). The intrusions form sills, dykes, small plugs, plutons several tens of $\mathrm{km}$ long, and impressive basin-parallel mafic dyke swarms (Figure 3c) that predate emplacement of most granitoid plutons of the Coastal batholith (Regan 1985; Pitcher and Bussell 1985). Locally, some granodiorite and monzogranite plutons are as old as the more mafic bodies indicating close temporal and spatial relations between mafic and siliceous magmas (Mukasa 1986). Although the plutons and their metamorphic haloes clearly crosscut structures in the country rock, some are cut by zones of intense ductile deformation and therefore were intruded during the deformation (Regan 1985). The mafic bodies are variable high-Al gabbro with bulk compositions that approximate olivine basalt (Regan 1985). Both field and geochemical evidence, such as profoundly different trace element characteristics and lack of any major element continua, indicate that rocks of the mafic suite are not comagmatic with the younger granitoid rocks of the Coastal batholith, but instead record a separate intrusive event (McCourt 1981; Regan 1985).

\section{The Coastal Batholith}

The Coastal batholith (Figure 1) is a $2000 \mathrm{~km}$ long linear batholith composed of a great number, perhaps 1000 or more, individual plutons (Cobbing et al. 1981; Pitcher 1985). There were two major pulses of plutonism within the batholith that postdated the suite of mafic to intermediate plutons and dykes emplaced at 105-101 Ma. The first occurred from about $91 \mathrm{Ma}$ to 82 Ma (Wilson 1975; Mukasa 1986). Following a break of 9-10 m.y. another suite was intruded in the range 73-62 Ma (Cobbing et al. 1981; Mukasa 1986).

Those interested in the petrographic details of the batholith will undoubtedly find the descriptions and maps in the memoirs by Cobbing et al. (1981) and Pitcher et al. (1985) to be without equal and the descriptions of the batholith here are summarized from those contributions augmented by other papers where noted. Most of the plutons of the batholith are composed of quartz diorite, tonalite, granodiorite, and monzogranite, with two periods of coeval batholith-parallel dyke swarms (Pitcher 1978). In a general sense, and like other Cordilleran batholiths, magmatism became more siliceous with time.

Originally the plutons were divided into genetically related units and super-units based on spatial, temporal, textural and modal variations, but U-Pb dating (Mukasa 1986) showed a more complex situation with 
much younger plutons intruding older suites. In general, it is exceedingly difficult to relate various plutonic phases in Cordilleran batholiths by fractionation and/or assimilation of wall rock: they are more complex assemblages (e.g. Memeti et al. 2012). Some workers, most notably Atherton et al. (1979) believed, based largely on low initial ${ }^{87} \mathrm{Sr} /{ }^{86} \mathrm{Sr}$, that rocks of the Coastal batholith came directly from the mantle; however, Cordilleran batholiths do not occur in regions where the crust is oceanic and there are several ways to create rocks with low initial ${ }^{87} \mathrm{Sr} /{ }^{86} \mathrm{Sr}$ (Hildebrand and Bowring 1984). In the case of the Coastal batholith, it appears clear that the early mafic magmas are predominantly mantle-derived, but even those are associated with more siliceous magmas. The main bulk of material within the Coastal batholith likely represents complex mixtures of heterogeneous mantle with highly variable, but dominantly intermediate, crustal material.

Following the early 91-82 Ma period well-documented in the extensive Lima and Arequipa sectors of the batholith, a second period of magmatism followed in the 73-62 Ma timeframe (Pitcher 1985, 1993; Mukasa 1986). This period of magmatism includes the great centred complexes and major swarms of batholith-parallel dykes that just predate the centred complexes. The age of dykes were bracketed to be between 73 and $71 \mathrm{Ma}$ and the younger ring complexes and centred intrusions were emplaced between 71 and $62 \mathrm{Ma}$, with the bulk of magmatism $70 \pm 2 \mathrm{Ma}$ (Mukasa 1986). Minor amounts of volcanism occurred at about $70 \mathrm{Ma}$ (Polliand et al. 2005) and it may have been related to the suite of centred complexes.

The centred complexes are 10-30 km wide and composed of individual plutons and ring-dykes of gabbro and diorite intruded by granodiorite and granite, in places granophyric (Bussell 1985). The dimensions of individual plutons with radii from 6-10 $\mathrm{km}$, the presence of ring dykes, and the overall centred nature of the complexes, led them to be interpreted as sub-cauldron intrusions (Bussell et al. 1976; Bussell 1985).

Granitoid plutons of the Coastal batholith range from calcic,
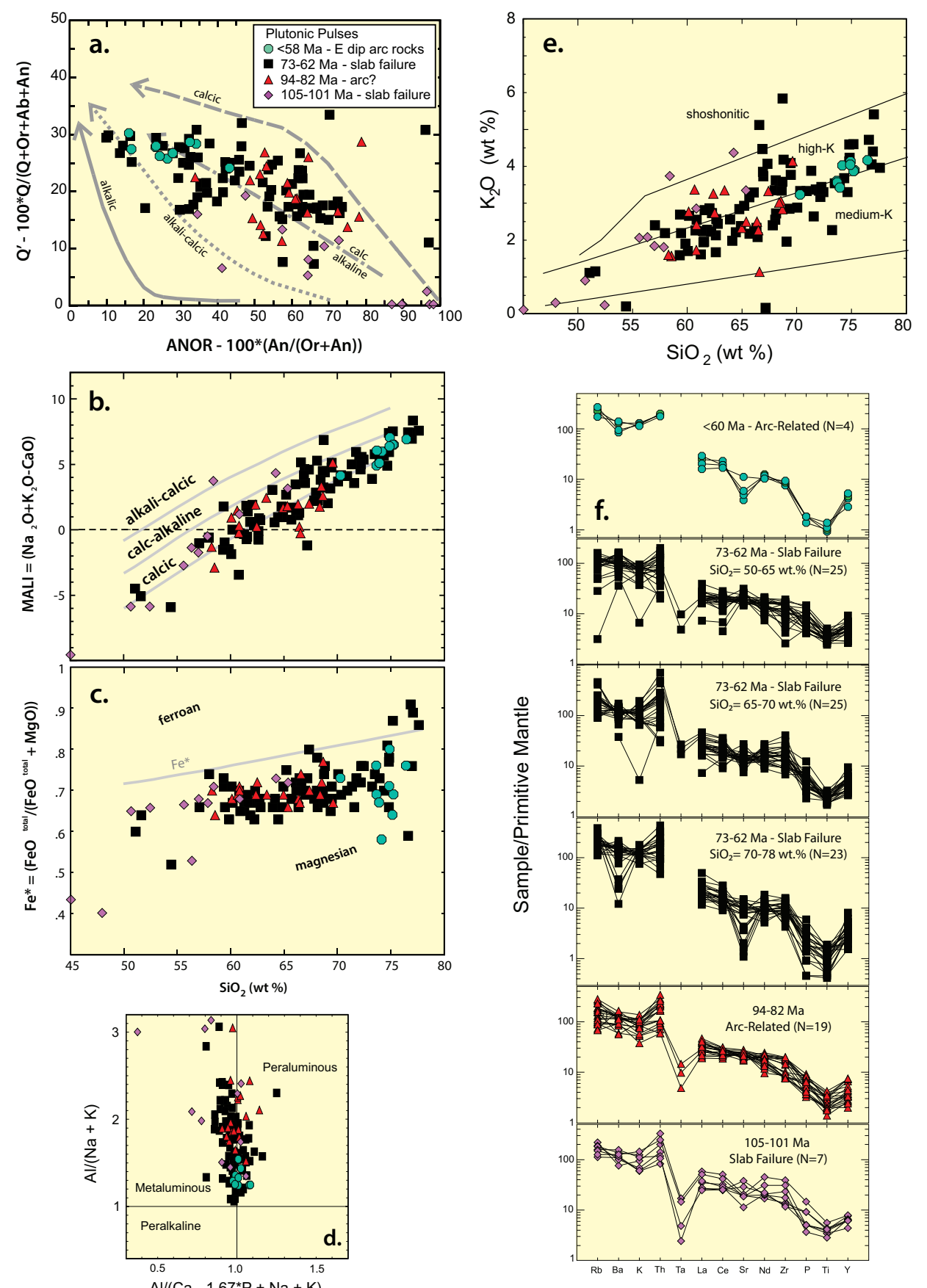

Figure 4. Geochemistry of the plutonic groups of the Coastal batholth plotted on: (a) CIPW normative Q' $\left(100^{*}(\mathrm{Q} /(\mathrm{Q}+\mathrm{Or}+\mathrm{Ab}+\mathrm{An}))\right.$ versus $\mathrm{ANOR}$ $(100 *(\mathrm{An} /(\mathrm{Or}+\mathrm{An}))$ classification diagram of Streckeisen and LeMaitre (1979) showing compositional trends for different representative types of plutonic suites from Whalen and Frost (2013); (b) $\mathrm{Na}_{2} \mathrm{O}+\mathrm{K}_{2} \mathrm{O}-\mathrm{CaO}$ (or MALI) vs. $\mathrm{SiO}_{2}$ and (c) $\mathrm{FeO}^{\text {total }} /\left(\mathrm{FeO}^{\text {total }}+\mathrm{MgO}\right)\left(\right.$ or $\left.\mathrm{Fe}^{*}\right)$ vs. $\mathrm{SiO}_{2}$ granitic rock classification diagrams of Frost et al. (2001). The boundary between ferroan and magnesian plutons was modified as suggested by Frost and Frost (2008); (d) a Al saturation index (ASI) [molecular $\mathrm{Al} /(\mathrm{Ca}-1.67 * \mathrm{P}+\mathrm{Na}+\mathrm{K})]$ versus molecular $\mathrm{Al} /(\mathrm{Na}+\mathrm{K})$ (inverted peralkaline index) diagram; (e) a $\mathrm{SiO}_{2}$ vs. $\mathrm{K}_{2} \mathrm{O}$ diagram with suite subdivisions after LeMaitre (1989) (low-, medium-, high-K) and Peccerillo and Taylor (1976) (high-K, shoshonitic); and (f) primitive mantle normalized extended element plots. Normalizing factors are from Sun and McDonough (1989). Analyses are from Pitcher et al. (1985). 


\section{Huarmey Cañete trough}

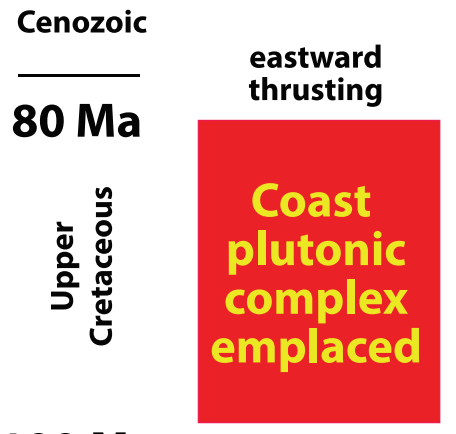

$100 \mathrm{Ma}$
$145 \mathrm{Ma}$
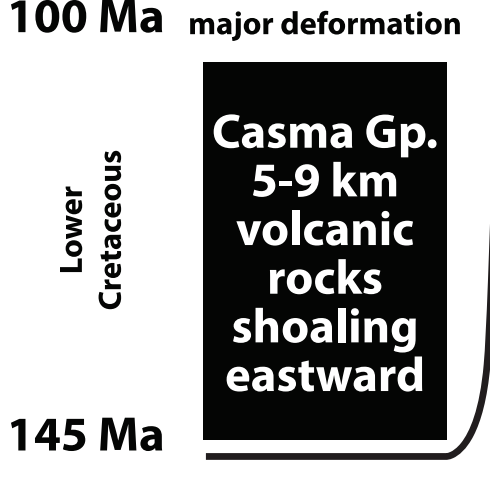

\section{West Peruvian basin}

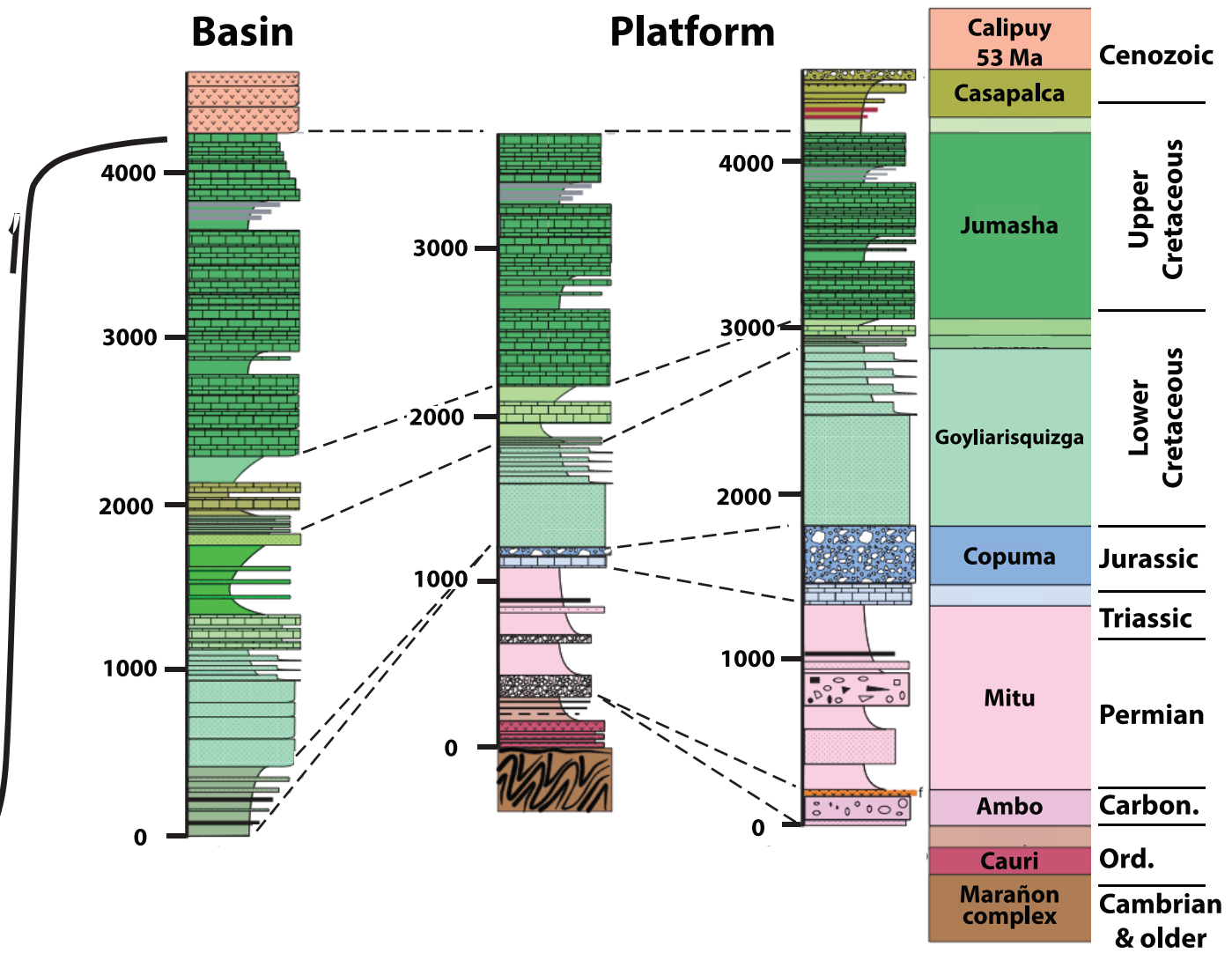

Figure 5. Stratigraphic sections of the West Peruvian Trough from Scherrenberg et al. (2012) compared and contrasted with simultaneous, or time-correlative, units and events in the Huarmey-Cañete trough basin to the southwest. The figure shows that the rock packages in each basin were unlikely to have been deposited within the same basin, or even adjacent to one another, during the Cretaceous and were more likely to have been juxtaposed during the Late Cretaceous-Early Tertiary.

calc-alkaline to alkali-calcic (Figure $4 \mathrm{a}$ and b). Based on their Fe* vs. silica values (Figure 4c), all but four high silica samples from the Coastal batholith are magnesian or oxidized, a distinctive feature of granitoid rocks formed at subducting margins (Frost et al. 2001). In general, the mainly metaluminous compositions (Figure 4d), amphibolebearing mineralogy, and common igneous microgranitic enclaves within more mafic end-members of suites (cf. Pitcher et al. 1985) indicate the Coastal batholith comprises I-type granitic rocks derived from infracrustal sources (Chappell and Stephens 1988). The Coastal batholith includes medium-K, high- $K$ and shoshonitic compositions and is consistently enriched in largeion lithophile elements (LILE) (Figure 4e). LILE-enrichment and negative Ta anomalies on extended element nor- malized plots (Figure 4f) are features of granitoid rocks formed within arc settings or derived from crustal sources. Coastal batholith variations in $(\mathrm{La} / \mathrm{Y})_{\mathrm{N}}, \mathrm{Sr} / \mathrm{Y}$, and $\mathrm{Y}$ bear both on the nature of the protoliths and the $P-T$ conditions of magma generation (Wang et al. 2007). The Sr $/ \mathrm{Y}<40$, $(\mathrm{La} / \mathrm{Y})_{\mathrm{CN}}<20$, and a lack of pronounced positive Sr anomalies on extended element plots (Figure 4f) exhibited by all Coastal batholith granitoid rocks, indicate formation within relatively thin crust under $P-T$ conditions with residual plagioclase and no residual garnet (Wang et al. 2007).

\section{Marañon Fold-Thrust Belt}

During deposition and deformation of rocks within the Huarmey-Cañete basin, as well as during the subsequent emplacement of the Coastal batholith, all of which are located west of the Tapacocha zone, thinly bedded siliciclastic and limey rocks accumulated to the east in the West Peruvian basin (Figure 5) to a thickness of at least $4000 \mathrm{~m}$ in the western off-shelf facies and about half that farther east on the west-facing platform (Wilson 1963; Scherrenberg et al. 2012; Pfiffner and Gonzalez 2013). The rocks span most of the Cretaceous (Figure 5) and there were no significant breaks in sedimentation until the uppermost Cretaceous when the platformal sequence was disconformably overlain by a thin sequence of calcareous marl capped by red cross-bedded sandstone, collectively interpreted to represent foredeep fill (Scherrenberg et al. 2012).

The foredeep developed when rocks of the Cretaceous West Peruvian basin were detached from lower struc- 
tural levels along a major décollement, folded, and thrust to the NE to create what is known as the Marañon fold-thrust belt (Scherrenberg et al. 2012, 2014). The belt is well developed between the Tapacocha zone and the Marañon complex and places western basinal facies rocks over more easterly platformal facies rocks. The structure ranges from tightly folded and isoclinal with steep axial fabrics to shallowly dipping beds with shallowly dipping northeast-vergent thrust faults (Pfiffner and Gonzalez 2013; Scherrenberg et al. 2014). The thrust belt continues southward into Bolivia (McQuarrie 2002).

The age of the deformation is bracketed to be latest Cretaceous to Early Tertiary based in part on $53 \mathrm{Ma}$ volcanic rocks of the Calipuy Formation that unconformably overlie rocks of the thrust belt (Atherton et al. 1985b; Petford and Atherton 1994) as well as the Late Cretaceous-Early Tertiary age of the Casapalca molasse (Scherrenberg et al. 2012). To the south, rocks of the Arequipa block were also thrust to the NE over Mesozoic sedimentary rocks prior to the emplacement of a $62 \mathrm{Ma}$ granitoid pluton (Ellison et al. 1989).

\section{Other Considerations}

Although the southern part of the Coastal batholith and its wall rocks are underlain by Mesoproterozoic basement of the Arequipa block, the nature of basement beneath the northern half was until recently uncertain, but now is thought to be Mesoproterozoic Arequipa block just as to the south (Romero et al. 2013). Metamorphic rocks of Paleozoic age outcrop in extreme NW Peru (Cardona et al. 2009) and appear to continue northward into Ecuador (Figure 1) where they are juxtaposed against Mesozoic eclogite and blueschist in the Amotape massif (Feininger 1980). The Paleozoic rocks of northern Peru and southern Ecuador apparently constitute basement within the Tahuín terrane, interpreted to be exotic with respect to South America (Feininger 1987). The relation between the northern terranes and the Arequipa block is unclear as exposure is poor but they must have been joined prior to emplacement of the Coastal batholith, which crosscuts both basement units.
Also outcropping in northern Peru-southern Ecuador, is the Cretaceous Lancones basin (Figure 1), which comprises a broadly folded, metalliferous volcanic section ranging in age from $\sim 105-90 \mathrm{Ma}$, just younger than most of the Huarmey basin; hosts Late Cretaceous plutons correlated with those of the Coastal batholith; and sits structurally between the Amotape and Olmos massifs (Jaillard et al. 1999; Winter et al. 2010). The earliest magmatism, 105-100 Ma, was a bimodal, tholeiitic to calc-alkaline basalt-dominated sequence of pillow basalt with associated volcanic massive sulphide deposits and low $\mathrm{Nb}$ and $\mathrm{Y}$ siliceous rocks; whereas younger 99-90 Ma magmatism involved both tholeiitic and calc-alkaline basalt, andesite and more siliceous lava (Winter 2008). Because the Lancones basin volcanic rocks are only openly folded and range in age from $\sim 105 \mathrm{Ma}$ to $90 \mathrm{Ma}$, they appear to be correlative with thin post105-100 Ma deformed volcanic rocks in the Huarmey basin and the early mafic suite within the Coastal batholith.

Seismic refraction, seismic reflection and gravity data collected in the northern sector at about $9^{\circ} \mathrm{S}$ coupled with drill cores and outcrops on islands suggest that basement to the west of the Huarmey basin on the Outer Shelf High is composed of crystalline rocks cut by intrusions (Jones 1981; Thornburg and Kulm 1981; Couch et al. 1981), now known to be part of the Arequipa block (Romero et al. 2013). Just to the east and beneath rocks of the Huarmey basin, seismic and gravity data show an arch-like structure of rock with a density of $3.0 \mathrm{~g} / \mathrm{cm}^{3}$ that was interpreted to be the result of crustal rupture and upwelling of mantle material into the crust (Jones 1981; Couch et al. 1981).

\section{INTERPRETATION}

While the Huarmey-Cañete basins are generally considered to represent the western part of a marginal basin (Cobbing 1978; Atherton et al. 1983, 1985a; Atherton and Webb 1989; Pitcher 1993), the tremendous thickness, some 5-9 km, of basalt and andesite, coupled with voluminous intermediate to siliceous ignimbrite and exposed Mesoproterozoic basement suggest to us that the magmatic rocks are the product of an arc built on continental crust. Consider that the average thickness of basalt formed at oceanic spreading ridges is about $0.5 \mathrm{~km}$ (Moores 1982; Dick et al. 2006) as basaltic eruptions only occur within the $1-3 \mathrm{~km}$ wide rift valley, which spreads outward and cools (Moore et al. 1974).

Thick sequences of arc rocks erupted and deposited within a basin are common as most continental arcs form within subsiding depressions or basins on crust of average or below average thickness (Levi and Aguirre 1981; Hildebrand and Bowring 1984; Busby-Spera 1988; Busby 2012). Modern examples include the Cascades, where the volcanoes sit in a half graben; the low-standing Alaskan Peninsula where volcanoes such as Augustine sit within Cook Inlet; the Kamchatka Peninsula of eastern Russia where majestic stratovolcanoes sit in huge fault-bounded troughs; New Zealand where the Taupo zone is actively extending as calderas and stratocones form; and the Central American arc where volcanoes are aligned in a long linear depression. The modern Andes are an exception to the pattern. Furthermore, the stratigraphy within pendants and wall rocks of Cordilleran batholiths provides no evidence of thick crust as they too sat at, or below, sea level during volcanism. The Sierra Nevada and Peninsular Ranges batholiths of North America were both low-standing during arc magmatism as documented by marine sedimentary rocks as young as $100 \mathrm{Ma}$ interbedded with the volcanic rocks (Fife et al. 1967; Allison 1974; Nokleberg 1983; Wetmore et al. 2005; Busby et al. 2006; Saleeby et al. 2008; Memeti et al. 2010; Centeno-García et al. 2011). Similarly, the Casma arc volcanic rocks described here were marine prior to $105 \mathrm{Ma}$ (Cobbing 1978, 1985;

Atherton et al. 1985a) as were those of the Jurassic-Cretaceous Ocoite arc in northern Chile (Levi and Aguirre 1981; Åberg et al. 1984).

Although the Huarmey-Cañete basin and the West Peruvian Trough are currently adjacent to one another, the lack of volcanic debris, coupled with the complete absence of the 100 Ma deformation within the West Peruvian Trough, preclude it being adjacent 
to the Huarmey-Cañete basin during its formation (Figure 4). Similarly, as the emplacement of the voluminous Coastal batholith occurred at the same time as sedimentation in the trough, one would expect some effect, such as uplift, on the western edge of the basin at $100 \mathrm{Ma}$, due to increased heat flux, but none is reported: the deformation in the eastern trough is much later, during the Late Cretaceous to Early Tertiary. Lastly, the facies of the two basins are incompatible because the West Peruvian Trough deepened westward whereas the Huarmey-Cañete shoaled to subaerial eastward (Figure

2). Thus, we conclude that the Huarmey-Cañete arc is exotic with respect to its current position in western Peru. To the east we see no evidence of another magmatic belt of the appropriate age that might be interpreted as a Cretaceous arc, so there is no reason a priori for subduction beneath South America to have been easterly during most of the Cretaceous. This model is similar to that proposed recently by Pfiffner and Gonzalez (2013).

Arcs generally shut down, are deformed and thickened when they collide with another arc, microcontinent or continent (Moores and Twiss 1985). Therefore, we attribute the magmatic shutdown and the $\sim 105 \mathrm{Ma}$ isoclinal folding of rocks within the basin to collision of the Huarmey-Cañete arc with an unknown block or terrane. Interestingly, the Peninsular Ranges batholith of Baja California, the Sierra Nevada Batholith of California and the Coast Plutonic Complex of British Columbia all have sutures of this age within them (Hildebrand 2013), suggesting some original continuity.

During collisions the competing buoyancy of the lower plate continental crust and the negative buoyancy of the attached oceanic slab ultimately lead to slab failure (McKenzie 1969; Isacks and Molnar 1969; Roeder 1973; Price and Audley-Charles 1987; Sacks and Secor 1990; Davies and von Blanckenburg 1995; Davies 2002; Atherton and Ghani 2002;). This is because the buoyancy forces resisting the subduction of continental lithosphere are as large as those pulling oceanic lithosphere downward (Cloos et al. 2005). Eventually, the greater density of the oceanic lithosphere causes the lower plate to break, predominantly by viscous necking (Duretz et al. 2012) at its weakest point, and sink into the mantle. This failure allows asthenosphere to upwell through the tear, melt adiabatically, and rise into the collision zone, where it interacts with the crust. The resulting magmas, which form linear arrays above tears in the descending slab, are linear upwellings flowing through the breach in the slab, but are compositionally heterogeneous as they reflect differences within both the mantle and crust and well as variable amounts of melting and mixing. They commonly overlap the terminal stages of deformation and are highly metalliferous (Solomon 1990; Cloos et al. 2005; Hildebrand 2009, 2013).

Because the early tholeiitic mafic suite - as well as temporally equivalent basalt of the Lancones basin - was emplaced during, to just after, deformation and appears unrelated to rocks erupted and emplaced both before and after them, we interpret them to represent the earliest slab failure magmas. Similarly, based on hafnium isotopes in zircon (Polliand et al. 2005), Maastrichtian volcanic rocks near Lima are thought to have little crustal input and may also be slab failure volcanic rocks related to the younger Late Cretaceous-Early Tertiary collision. Thus, in the case of the Coastal batholith both slab failure volcanic rocks and plutons exist. Nearly identical sequences of magmatism, which occurred as deformation was waning and with similar plutonic rock compositions and temporal relations, were documented for the Silurian of western Newfoundland by Whalen et al. (2006) and the Pliocene of the Eastern Carpathians (Gîrbacea and Frisch 1998). In both cases, mafic break-off magmas rose rapidly into the collision zone and were followed by a longer period of calc-alkaline to shoshonitic magmatism.

The eastward-vergent folds within rocks of the Huarmey-Cañete arc suggest, but do not prove, that the lower plate lay to the east: nevertheless, as stated, there is no evidence for deformation or arc magmatism of this age in cratonic Peru. Therefore, we suggest that the Arequipa block and its unknown collider were both offshore and transected by an arc-parallel strikeslip fault, common to zones of oblique convergence (Fitch 1972) and that meridional migration during the collision separated the two. Such a scenario would explain the NE cross-folds that folded the earlier NNW isoclines yet predated the early mafic suite (Figure 3a).

Hildebrand (2013) recognized that several Cordilleran batholiths of North America, such as the Peninsular Ranges, Sierran and British Columbia Coast batholiths were composed of two phases: an early arc phase and a younger post-deformational phase, which he interpreted to represent slabfailure magmatism due not only to its post-deformational timing, but also to the exhumation and erosion related to doubling of the crust during collision. The age of collisional deformation in the North American batholiths is about $100 \mathrm{Ma}$ - the same as in the Coastal batholith of Peru.

One batholithic segment in North America has long been recognized as an out-of-place orphaned block: the Salinian block (Ross 1978), located just west of the San Andreas fault in central California. There, amphibolite-granulite facies gneiss and schist lacking pure quartzite and carbonate rocks characteristic of the North American margin (Ross 1977) are cut by 100-82 Ma plutons ranging in composition from gabbro to granodiorite (Mattinson 1978, 1990; Kistler and Champion 2001; Kidder et al. 2003; Chapman et al. 2014), which is similar to the setting and magmatism of slab failure sectors in the other batholiths. Thus, the Salinian block appears to be missing its western arc component (Page 1970, 1982) and, with 100-82 Ma magmatism, appears to represent the slab failure half of a Cordilleran batholith, which makes it a reasonable candidate for the exhumed eastern half of the Coastal batholith of Peru with its Arequipa-Antofalla basement (Loewy et al. 2004). In fact, paleomagnetic data from Upper Cretaceous and Paleocene sedimentary rocks of the Salinian block indicate that they were deposited 2800-2100 $\pm 500 \mathrm{~km}$ south of their present location (Champion et al. 1984), although there is some controversy about the data based on study of different rocks (Whidden 

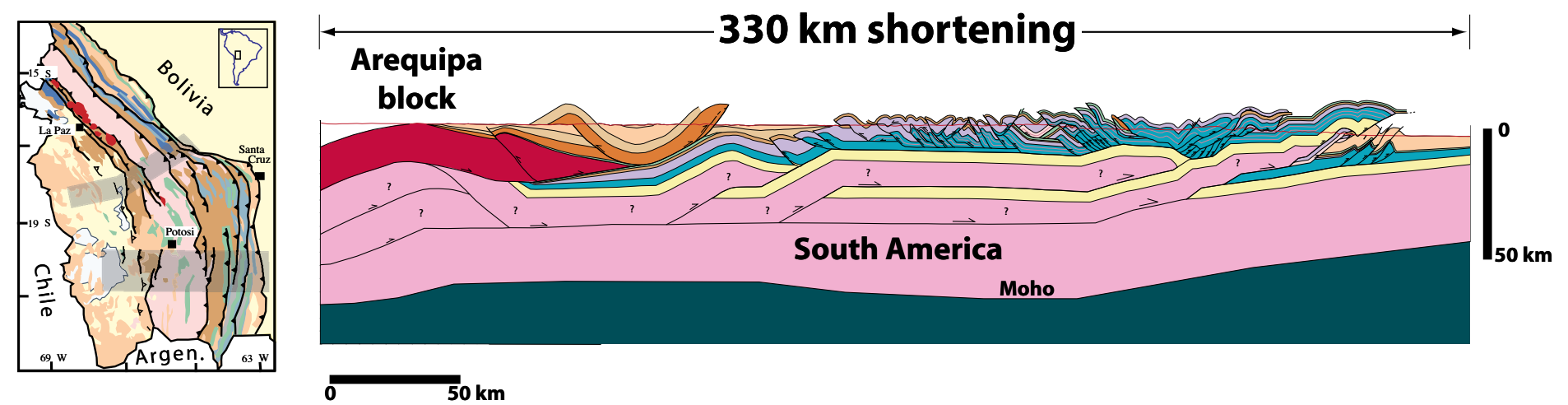

$330 \mathrm{~km}$ shortening

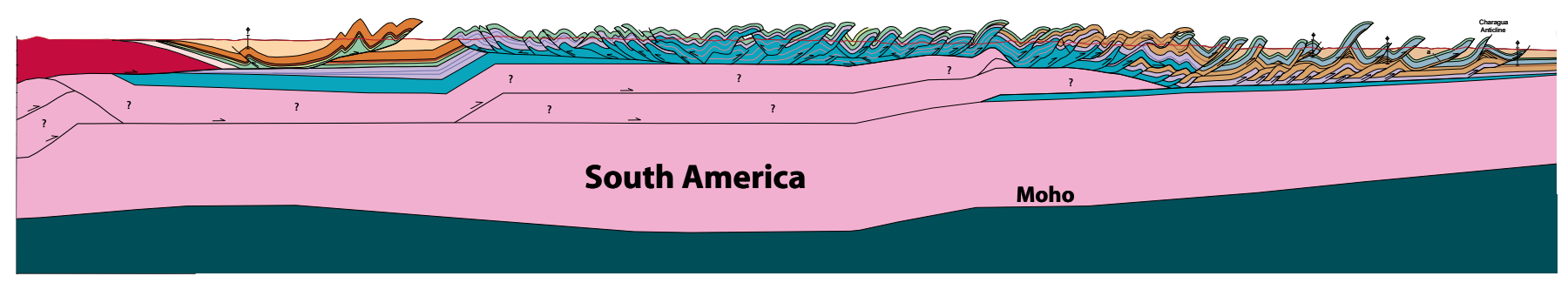

modified from McQuarrie, 2002

\begin{tabular}{|c|c|c|c|}
\hline Miocene & Cretaceous & Devonian & Cambrian \\
\hline $\begin{array}{l}\text { Eocene-Olig } \\
\text { Paleocene }\end{array}$ & $\begin{array}{l}\text { Jurassic-Triassic } \\
\text { Carboniferous }\end{array}$ & $\begin{array}{l}\text { Silurian } \\
\text { Ordovician }\end{array}$ & Precambrian \\
\hline
\end{tabular}

Figure 6. Interpretive balanced cross-sections through the central Andean fold-thrust belt after McQuarrie (2002) illustrating Arequipa block sitting atop inferred South American crust.

et al. 1998). Nevertheless, paleontological data suggest that the fauna of Salinia are a reasonable match with those in the Peninsular Ranges of southern California (Elder and Saul 1993), which are considered to be far traveled (Hagstrum et al. 1985). Wherever they were during the mid-Cretaceous, we know of no other blocks in the Cordillera that match as well as Salinia and the Coastal batholith of Peru.

Although it is difficult to separate slab failure magmas from subsequent arc magmas, except that slab failure magmas are syn- to closely postcollisional, in the Peruvian case given the differences in major and trace element trends, and the 10 m.y. gap between the mafic intrusions and the 91-82 Ma bodies, it is possible that only the early mafic suite represents slab failure magmatism and that plutons of the 91-82 Ma suite formed above a westward-dipping subduction zone that lay beneath an ocean between South America and the Are- quipa terrane. Whatever the ultimate nature of the magmatism, the ocean closed during the Late CretaceousEarly Tertiary when the Arequipa block, with its volcanic cover and plutonic complexes, docked with western South America to create the eastwardvergent Marañon fold-thrust belt. The eastward vergence of the fold-thrust belt, the absence of Mesozoic magmatism older than $72 \mathrm{Ma}$ in this region of cratonic South America, and the many plutons of this age range in the Coastal batholith (Mukasa 1986) combine to demonstrate westward subduction of the South American craton beneath the Arequipa terrane. A westward subduction scheme beneath the Arequipa block is also supported by a Late Cretaceous-Early Tertiary foredeep and east-vergent thrust belt to the south in the Altiplano of Bolivia where, as documented by structure sections (Figure 6) and drill holes, the Arequipa block sits along the western margin of the fold-thrust belt and atop the western edge of cratonic
South America (McQuarrie 2002; DeCelles and Horton 2003).

Following the 82 Ma shutdown of magmatism in the Coastal batholith, a second period of magmatism started some 9-10 m.y. later and appears to have postdated the accretion of the Huarmey rocks and the first phase of the Coastal batholith to the South American craton. This period of magmatism was characterized by voluminous and widespread batholithparallel, intermediate composition dyke swarms in the age range 73-71 $\mathrm{Ma}$ and centred complexes emplaced between $72 \mathrm{Ma}$ and $64 \mathrm{Ma}$ (Pitcher 1985; Mukasa 1986). The dyke swarms attest to widespread batholith-normal extension during their emplacement, which Pitcher and Bussell (1985) suggested occurred during uplift or doming of the region as a whole. We interpret these magmatic products as the direct result of slab failure of the west-dipping South American lithosphere during the Late Cretaceous-Early Tertiary collision that produced the Maraña 
fold-thrust belt. If correct, the preand post-collisional plutons and dykes constrain the collision to have been 77 $\pm 5 \mathrm{Ma}$

It thus appears that the Coastal batholith contains two periods of slab-failure magmatism with a period of arc magmatism sandwiched between them: (1) an older period in the range 105-101 Ma; and (2) a younger period that started at $77 \pm 5$ $\mathrm{Ma}$ and terminated at about $62 \mathrm{Ma}$. The concurrence of two periods of slab-failure magmatism and a period of subduction-related plutonism in the same linear trend over such a long period of time is most likely related to the narrow width of the HuarmeyCoastal batholith-Arequipa block and its history of subduction and collision. It should serve as a cautionary tale for those geologists who argue that arcs oscillate back and forth between compression and extension simply due to slab dip, obliquity, or convergence rate (Ducea 2001; Ramos 2009, 2010a; DeCelles et al. 2009; Paterson et al. 2012b). In the case of the Arequipa terrane the variations are due to complex plate interactions that led to three periods of subduction, two collisions, and two periods of slab-failure magmatism. Thus, the answer to Shackleton's insightful question, while complex in detail, relates more to the narrow nature of the Arequipa terrane due to the loss of its eastern half, and two periods of slab failure with consequent upwelling mantle: it was twice the crustal lid to linear mantle upwelling. Following terminal collision at $77 \pm 5$ $\mathrm{Ma}$ and an initial period of slab-failure magmatism, new eastward subduction led to magmatism of the Calipuy Formation at $53 \mathrm{Ma}$ even farther eastward and for the first time during the Cretaceous on rocks of the South American craton (Figure 5).

Most workers have related the broad arch of dense rocks within the crust of the Western Cordillera to represent upwelling mantle during eruption and extension of the crust related to the Huarmey basin (Atherton and Webb 1989) however, upwelling mantle resulting from two periods of slab failure postdated the terminal collision and could also have caused such a feature. Why it doesn't occur to the south is unclear, but the volcanic sequences seem thinner to the south and so there may have been less extension within the region.

\section{CHEMISTRY}

We recognize that the Coastal batholith has served as one of the archetypical Cordilleran batholiths generally hypothesized by geologists to have been generated by subduction of oceanic lithosphere beneath a continental margin (Pitcher et al. 1985) and so served as a model, both petrographically and geochemically, for similar belts of all ages worldwide. Analyses from the Coastal batholith are by today's standards incomplete, and most of the principal workers have retired or died. That said, we decided to take a look at the existing chemistry (Pitcher et al. 1985) to see if there are significant differences between the various settings we outlined. We believe it important because the centred complexes of the Coastal batholith, here suggested to be of slab-failure origin, are quite similar in overall form and composition to post-collisional phases of North American batholiths, such as the La Posta Suite of the Peninsular Ranges batholith (Silver and Chappell 1988; Clinkenbeard and Walawender 1989; Walawender et al. 1990; Kimbrough et al. 2001; Lee et al. 2007) and plutons of the Sierran Crest magmatic event within the Sierra Nevada batholith (Bateman 1992; Coleman and Glazner 1998; Paterson et al. 2012a, b).

While we strongly believe that the best evidence for slab-failure magmatism is its timing in that it overlaps with and just follows collision, we nevertheless examined various plots of the data as shown on Figure 4 to ascertain if there are visible differences between arc-type and slab-failure plutonic events within the Coastal batholith. We suggest the following first-order differences.

1. Arc-related Coastal batholith plutonic groups span lower silica ranges $(\sim 14 \mathrm{wt} . \%$ for the $94-82$ Ma group and $\sim 5 \mathrm{wt} . \%$ for the $<$ 60 Ma group) than the slab-failure groups $(\sim 22$ wt. $\%$ for the $<105-101$ Ma group and 25 wt. $\%$ for the 73-62 Ma group) (Figure 4).

2. The arc-related plutonic groups are medium- to high- $\mathrm{K}$ and calcic to calcic-alkalic, whereas the slabfailure groups are more variable and include some alkali-calcic to alkalic and shoshonitic compositions (Figure 4). Also, the 73-62 Ma slab-failure group includes some ferroan (reduced) samples (Figure 4), considered to reflect an intra-plate setting (Frost et al. 2001).

3. There do not appear to be obvious differences in normalized trace element abundances or patterns between arc-related and slab-failure plutonic groups (Figure 4). However, zirconium, in $>60 \mathrm{wt}$. $\%$ silica arc-related samples, ranges from 84 to $222 \mathrm{ppm}$, versus 49 to $454 \mathrm{ppm}$ in slab-failure samples, which yielded zircon saturation temperature (Watson and Harrison 1983) ranges of $721^{\circ}$ to $785^{\circ} \mathrm{C}$, and $629^{\circ}$ to $866^{\circ} \mathrm{C}$, respectively. This suggests that granitoid magmas generated during slab-failure likely formed under higher partial melting temperatures than those formed within an arc setting.

The apparent differences between the arc-related and slab-failure plutonic groups may reflect fundamental differences in petrogenetic processes. The greater compositional range and higher temperatures of the slabfailure plutonic groups may indicate greater thermal and material input from the mantle during their generation. Their range to more alkalic compositions may reflect input from enriched asthenospheric mantle material during slab failure versus depletedmantle input to the arc-related plutonic groups. The association of zoned intrusions in the $77 \pm 5 \mathrm{Ma}$ slab-failure group may reflect these magmas being higher temperature melts, as indicated by zircon saturation temperatures. Such melts would tend to rise higher in the crust and contain little or no restite, rendering them less viscous, thus facilitating mixing and/or crystal fractionation/differentiation. In contrast, lower temperature arc-related granitoid intrusion would tend to form from restiterich and more viscous magmas that cannot readily fractionate or mix with other magmas. In any case, if the original samples or powders could be located, and funds were available, it would be worthwhile to analyse them for a 


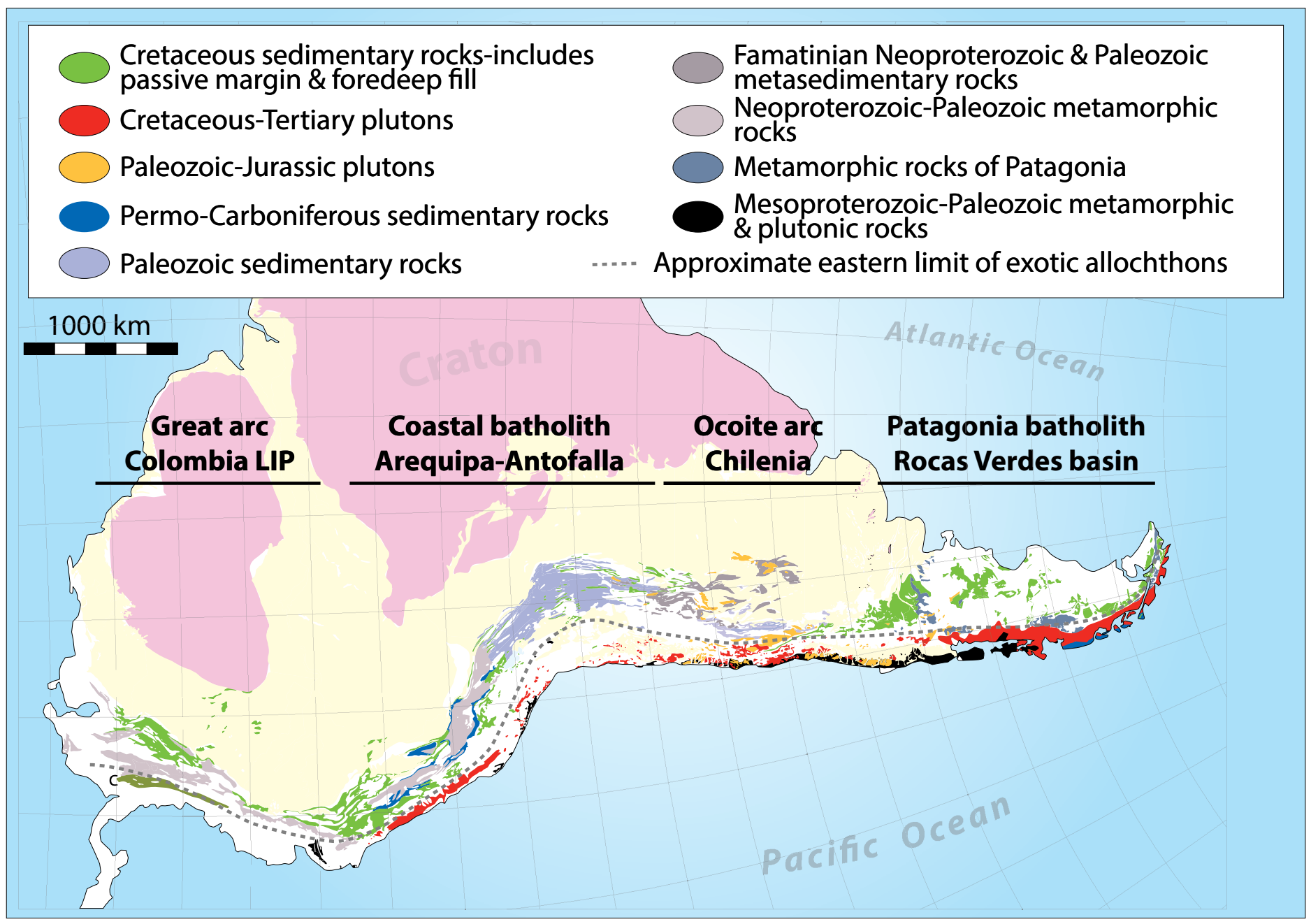

Figure 7. Geological map of the Andes with volcanic cover removed to illustrate the four main Late Cretaceous-Early Tertiary collisional regions discussed in the text and the close spatial relationship between Cretaceous foredeep deposits in green and Paleozoic-Precambrian basement of western South America. Olive green labeled C is accreted LIP and Great Arc as shown in detail on Figure 7. Modified from Schenk et al. (1997).

full spectrum of trace elements by modern methods.

\section{REGIONAL CONSIDERATIONS}

The realization that the $2000 \mathrm{~km}$-long Coastal batholith and its basement(s) were exotic with respect to South America during the Cretaceous caused us to re-examine the geology over the entire length of western South America looking at known similarities and differences, and provides the final key to unlocking the tectonic development of the margin during the Cretaceous. In this section we discuss briefly our findings for 3 additional sectors (Figure 7) and then go on to compare them with recent analyses of North America. We then present a new model that contrasts with the more popular hypothesis of long-lived eastward sub- duction beneath western South America.

Within the Colombia-Ecuador sector to the north, west-dipping subduction of cratonic South America beneath the Great Arc of the Caribbean and the ColombianCaribbean oceanic plateau (Figure 8) led to Campanian ( $75 \mathrm{Ma}$ ) emplacement of arc fragments and pieces of oceanic plateau upon western South America throughout western Colombia and the northern three-quarters of western Ecuador (Altamira-Areyán 2009; Pindell and Kennan 2009; Jaillard et al. 2009; Villagómez and Spikings 2013). To the east a foreland basin, extending from the Caribbean Sea as far south as Bolivia, developed during the Late Cretaceous-Early Paleocene as a response to the thrust loading of the exotic terranes (Sempere et al. 1997).

To the south the composite Mesoproterozoic Arequipa-Antofalla block continues into Bolivia and Chile (Loewy et al. 2004; Ramos 2008, 2010b) and there sits atop South American cratonic crust (Figure 9) directly west of Upper CretaceousEarly Tertiary foredeep deposits (DeCelles and Horton 2003; Arriagada et al. 2006) and a fold-thrust belt (Figure 6) with about $330 \mathrm{~km}$ of shortening (McQuarrie 2002; McQuarrie et al. 2005). The occurrence of the exotic allochthons coincident with the thickest parts of the Andean crust (Allmendinger et al. 1997) suggests that much, if not all, of the crustal thickening might be accounted for by partial westward subduction of the South 


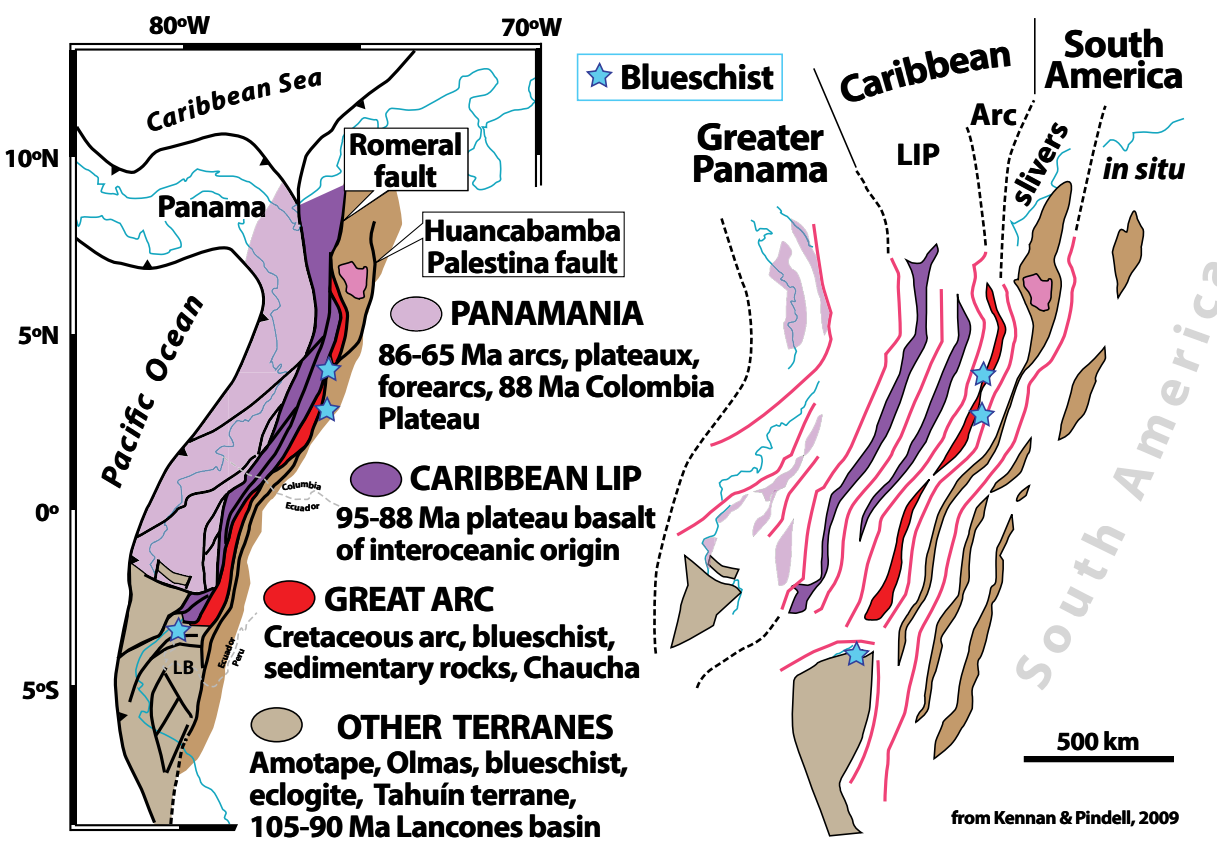

Figure 8. Geological sketch map showing the distribution of terrane fragments in the Colombian and Ecuadorian sector of the Andes and an exploded view for greater clarity. Modified from Kennan and Pindell (2009). As discussed in the text, part of the more extensive Great Arc of the Caribbean and the ColombianCaribbean oceanic plateau were emplaced at about $75 \mathrm{Ma}$ above the west-facing passive margin of South America. LB-Lancones basin

$15^{\circ}$

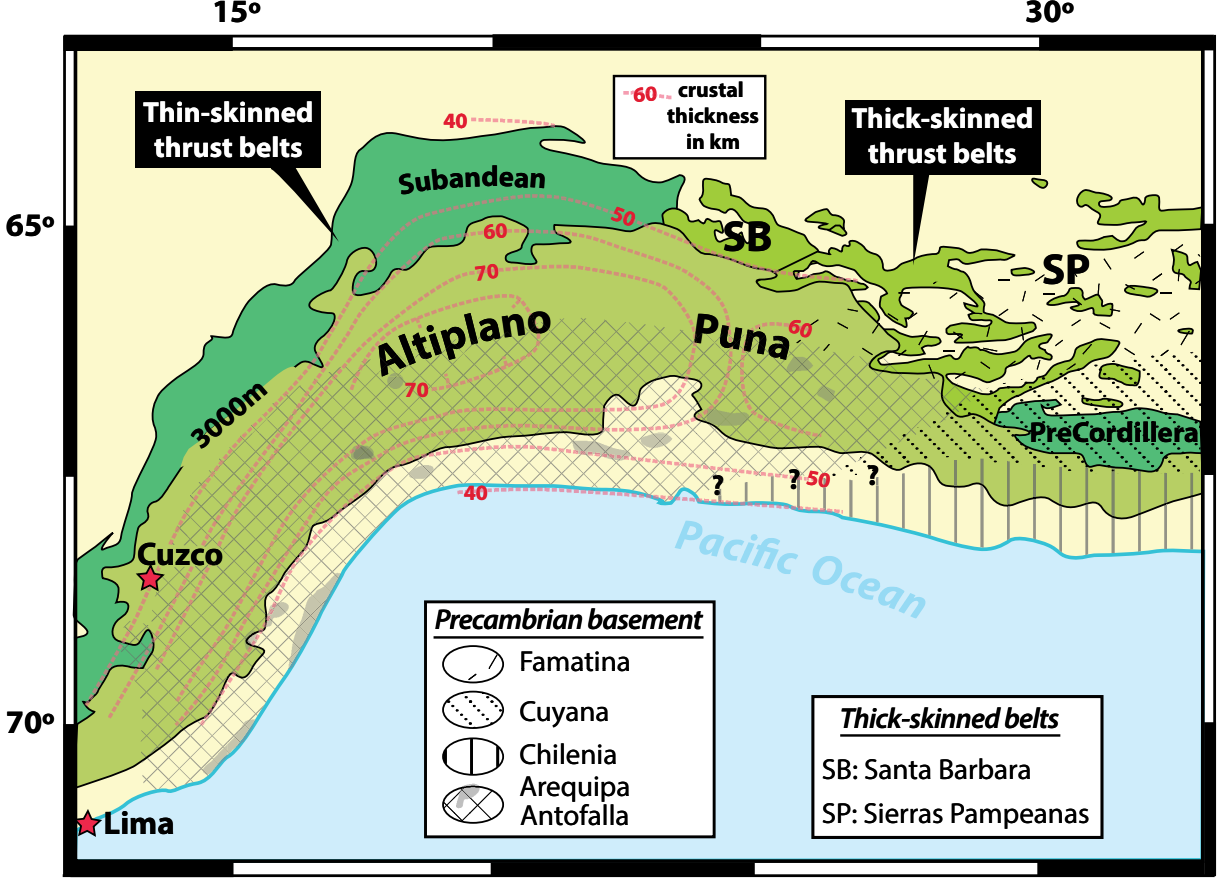

Figure 9. A generalized map showing distribution of thin- and thick-skinned thrust belts, distribution of basement blocks, and crustal thicknesses in the Altiplano \& Puna regions of the central Andes illustrating extent of the exotic Arequipa-Antofalla blocks; darker areas approximate basement outcrops. Modified from Allmendinger et al. (1997) and Ramos (2008).
American margin and emplacement of the allochthons atop it. Some younger, even modern, thrusts near the eastern topographic break might relate to gravitational spreading of the overthickened and uplifted collisional crust.

Still farther south, relations are complex and incompletely resolved, but a $>10 \mathrm{~km}$ thick synclinal accumulation of Jurassic to Late Cretaceous volcanic and allied rocks, collectively termed the Ocoite arc, sits unconformably upon deformed and metamorphosed Paleozoic rocks rocks of Chilenia, a Neoproterozoic basement terrrane (Levi and Aguirre 1981; Åberg et al. 1984; Ramos 2010b). Basement outcrops are scarce and their relations to the more easterly Cuyania terrane are obscure (Ramos 2010b). East of the volcanic rocks a well-developed, but largely eroded, foredeep basin and easterly vergent fold-thrust belt had developed by the Late Cretaceous (Morabito and Ramos 2012). The belt (Figure 10) is broken into several pieces by younger faults and was eroded during younger exhumation: different sectors have different names such as Malargue, Chos Malal, Agrio, and Aluminé fold-thrust belts (Cobbold and Rossello 2003; Howell et al. 2005; Ramos and Folguera 2005; Zapata and Folguera 2006). East of the Neuquén Precordillera, a N-S linear band of late kinematic andesitic to rhyodacitic volcanic rocks and subvolcanic porphyry, collectively known as the Neunauco Belt, were emplaced between $75 \pm 3$ $\mathrm{Ma}$ and about $60 \mathrm{Ma}$ (Morabito and Ramos 2012; Spagnuolo et al. 2012). Because they were intruded at the tail end of deformation we interpret them as slab-failure magmas formed when the westward-subducting slab failed during the collision.

In the Patagonian Andes the 157-75 Ma Patagonian batholith was emplaced atop the South American craton during the Late

Cretaceous-Early Paleocene by closure of the oceanic Rocas Verdes basin along a series of eastward-vergent, westward-dipping thrust faults (Figure 11), which contain slices of ophiolite and document westward subduction (Dalziel et al. 1974; Wilson 1991; Kraemer 2003; Ghiglione et al. 2010; Maloney et al. 2011). Eastward propagating orogenic wedges of the Magellanes 


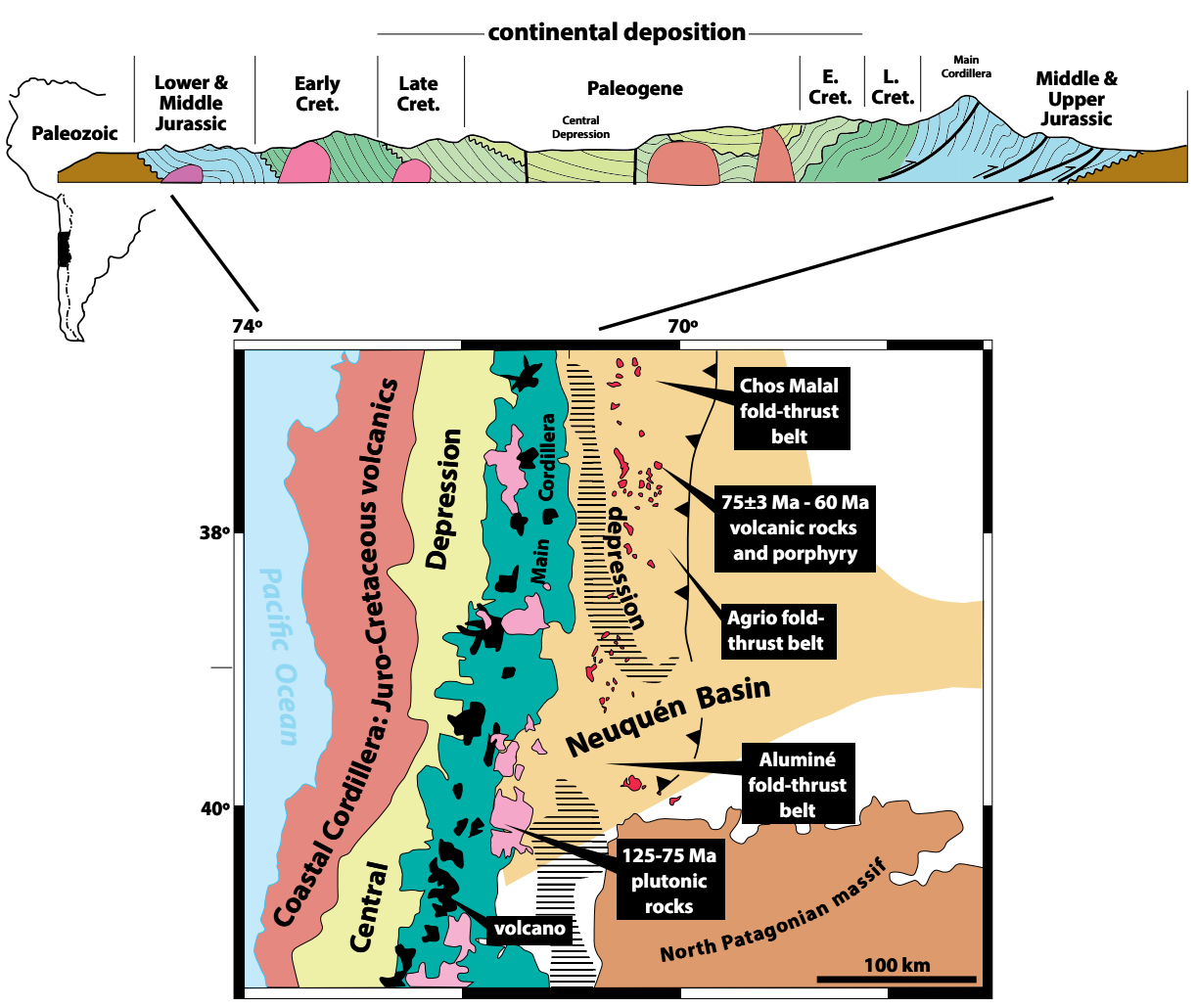

Figure 10. Schematic cross-section at $\sim 33^{\circ} \mathrm{S}$ through the Mesozoic arc terrane of central Chile illustrating its overall synclinal form and its location relative to the Late Cretaceous-Early Tertiary fold-thrust belts. The $75 \pm 3 \mathrm{Ma}$ volcanics and hypabyssal porphyries intruded and overlie the thrust faults and are here interpreted to represent slab-failure magmas. Generalized cross-section from Åberg et al. 1984; Levi and Aguirre 1981. Map compiled from sources cited in text. In addition to the fold-thrust belt in the Neuquén foreland basin, the Main Cordillera is also a Late Cretaceous eastward-vergent thrust stack that at $33^{\circ} \mathrm{S}$ forms the highest and narrowest section, known as the Aconcagua thin-skinned fold-thrust belt (see Figure 8 in Ramos et al. 2004). Horizontal lines are post-collisional fault-bounded depressions.

and Malvinas basins developed in front of the thrusts during the Campanian and were subsequently incorporated into the thrust sheets (Macellari et al. 1989; Suarez et al. 2000; Olivero and Malumián 2008; Ghiglione et al. 2010). Magmatism within the batholith continued to the time of collision at $\sim 75$ $\mathrm{Ma}$ then stopped. Much younger plutons relate to eastward, post-collisional subduction.

Just as the Great Arc of the Caribbean passed between North and South America to form the Antillean arc today, the Scotia arc (Barker et al. 1991) represents a Pacific realm that migrated into the Atlantic Ocean (Alvarez 1982; Pugh and Convey 2000) through the gap between South America and Antarctica as originally suggested by Moores (1970). Eastward migration of the arc left scattered traces strewn along its transform margins (Garrett et al. 1987).

It appears then that during the Late Cretaceous-Early Tertiary, large crystalline terranes, containing Jurassic-Cretaceous magmatic arcs, were emplaced upon the entire west coast of South America, and not necessarily only during the Paleozoic as commonly hypothesized (Vaughan et al. 2005; Ramos 2008, 2009, 2010a). In our alternative model, eastward-vergent Late Cretaceous-Early Tertiary fold-thrust belts and associated eastwardly migrating foredeep basins developed on cratonic South America nearly synchronously with collision of a composite arc-bearing ribbon continent. When coupled with the accretion of the ribbon continent, and the lack of arc magmatism on South America, they indicate westward subduction of
South American lithosphere during the Cretaceous. In many cases basement within these terranes is poorly exposed, but where observed is commonly Mesoproterozoic. The original provenance of the terranes is obscure.

\section{HEMISPHERIC IMPLICATIONS}

It has not escaped our attention that the deformational scheme outlined here for South America is strikingly similar to that of the North American Laramide event (Hildebrand 2013, 2014), but before discussing the North American geology, we need briefly mention some new tomographic advances arising from improved computing power and high-resolution seismic arrays, such as USArray (Williams et al. 2010), and also from recently developed kinematic models for plate motions in deep mantle reference frames based on seafloor spreading history, hotspot migration, paleomagnetism, and moving continents (Müller et al. 1993; O’Neill et al. 2005; Torsvik et al. 2008a, b; Doubrovine et al. 2012; Shepard et al. 2012; Seton et al. 2012).

Sigloch and Mihalynuk (2013) analysed tomography of the 'fast' regions in the mid-mantle beneath North America, readily interpreted as folded relict oceanic slabs (Grand et al. 1997), and combined the paleogeographical models for the Jurassic-Early Cretaceous westward migration of North America during the opening of the Atlantic Ocean with observations that the largest mantle anomaly, which is a steeply inclined slab wall in the transition zone and lower mantle that extends for over $40^{\circ}$ of latitude beneath eastern North America (Sigloch 2011), must have formed during westward, not eastward, subduction. Eastward subduction beneath North America during westerly migration of North America as the Atlantic Ocean opened implies that both the trench and continent would have been coupled and migrated westward together, and thus have left an inclined, not vertical, slab. Hildebrand (2014) found that the Sigloch and Mihalynuk (2013) model, once corrected for paleomagnetic inclination errors (Kent and Irving 2010), matched the time and place for initial impingement of the Cordilleran Ribbon Continent in the Great Basin region during the Sevier 


\section{SW}

$150 \mathrm{Ma}$

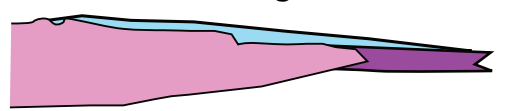

NE

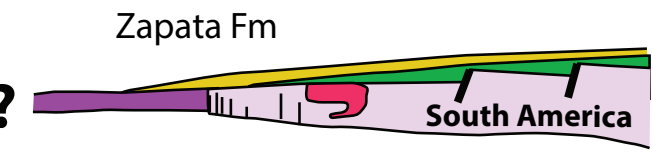

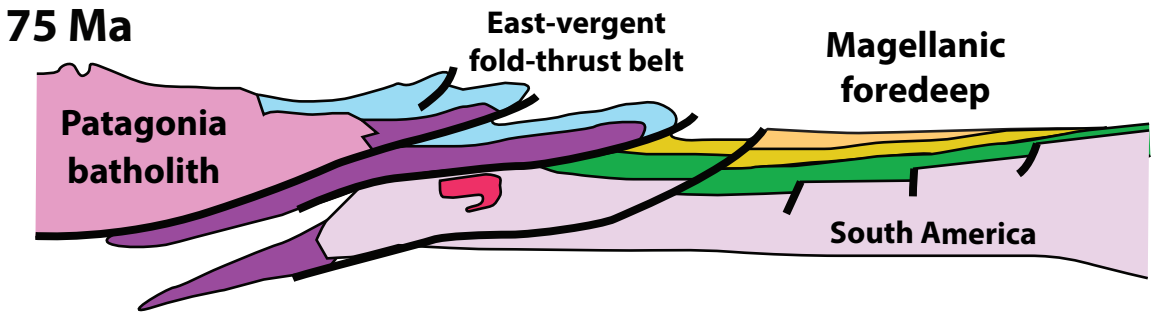

Figure 11. Schematic cross section of Rocas Verdes basin and its closure illustrating the unknown width of the basin and the westerly subduction of South American cratonic crust during its closure. Modified from Maloney et al. (2011).

event, and some 20 m.y. later the more widespread terminal collision during the Laramide event.

The mantle tomography fits well with known geology, for all along the entire western margin of North America, eastward-vergent thrusts and foredeep basins developed on the craton during the Late Cretaceous-Early Tertiary. Unaware of the mantle tomography arguments, Hildebrand (2009, 2013) and Johnston (2008) presented models to explain the thrusts and foredeep, based entirely on geological observations, in which the North American margin was partially subducted to the west beneath an exotic, arc-bearing ribbon continent. The subsequent publication of the tomographic model thus provided entirely independent verification of the westerly subduction model. We briefly describe some key regions (Figure 12) from north to south as examples to illustrate the breadth of terminal Laramide collision.

In Alaska, rocks of the Valanginian-Cenomanian Kahiltna basin were metamorphosed and thrust northward at $\sim 74 \mathrm{Ma}$, coincident with development of the Campanian-Maastrichtian Cantwell basin, a thrust-top basin formed during the deformation caused by the accretion of Wrangellia to the paleo-Alaskan margin along a well-defined geophysical and detrital zircon provenance break (Ridgway et al. 2002; Trop and Ridgway 2007; Hults et al. 2013). Late CretaceousEarly Tertiary northward-vergent thrusts and folds also deformed Early Cretaceous features in northern Alaska, including apparent basement duplexing in the Brooks Range (Moore et al. 1997).

In the Canadian segment, rocks of the North American continental terrace were separated from their basement along a detachment located within Cambrian shale, folded, and thrust eastward to form the Rocky Mountain fold-thrust belt during the Late Cretaceous-Early Tertiary (Price and Mountioy 1970; Price 1981; Price and Fermor 1985; Fermor and Moffat 1992). A thick, and northward migrating, clastic wedge of Campanian-Paleocene age developed to the east in the foreland basin during this deformation (Catuneanu et al. 2000; Ross et al. 2005; Larson et al. 2006).

Farther west in the Coast Plutonic complex (Figure 12) a linear band of exhumation is found along with a major firestorm of Late CretaceousEarly Tertiary plutons (Armstrong 1988), which Hildebrand (2009, 2013) related to slab failure following accretion of Wrangellia at about $80 \mathrm{Ma}$ (see also Gehrels et al. 2009).
Thrusting was apparently ongoing from Sevier to Laramide time within the North American margin of the Great Basin sector, but it was much subdued (e.g. DeCelles and Coogan 2006; Yonkee and Weil 2011). Intense deformation and metamorphism occurred within the Great Basin between 85 and $75 \mathrm{Ma}$ (Camilleri et al. 1997; McGrew et al. 2000) and the classic thick-skinned deformation of the Colorado Plateau region started during the Maastrichtian and continued into the Tertiary (Dickinson et al. 1988; Lawton 2008).

In pre-San Andreas paleogeographic reconstructions (Powell 1993), another zone of Laramide deformation strikes obliquely across Arizona and through the Southern California Transverse Ranges (Figure 12) where it is truncated at the coast. Orocopia and Pelona schist (Jacobson et al. 2007) is associated with this zone, which suggests that it had once been joined with the similar Swakane gneiss of the North Cascades (Matzel et al. 2004; Hildebrand 2013, 2014). Similarly, a major swarm of Late Cretaceous-Early Tertiary post-collisional plutons - considered by Hildebrand (2013) to have been generated by slab failure - trending through the Transverse Ranges, the Mojave and Sonoran deserts, and on through western Mexico would also match with similar age plutons of the Cascades and Idaho (Figure 12).

A continuous Late Cretaceous-Paleocene foreland fold-thrust belt and related foredeep occur throughout north-central and eastern Mexico just west of the Gulf of Mexico (Eguiliz de Antuñano et al. 2000). It formed during the terminal accretion of the Guerrero superterrane sector of the Cordilleran Ribbon Continent (Tardy et al. 1994; Centeno-Garcia et al. 2008, 2011). The western margin of Oaxaquia and Mixteca were deformed in the Late Cretaceous-Early Tertiary in a dominantly east-vergent fold-thrust belt (Suter 1984, 1987; Hennings 1994; Fitz-Díaz et al. 2012) and the Tampico-Misantla foredeep developed in front of the advancing thrusts (Busch and Gavela 1978).

We step aside to mention that some 20-25 m.y. earlier at $100 \mathrm{Ma}$, and a bit farther west than the Laramide deformational front, the Santiago 


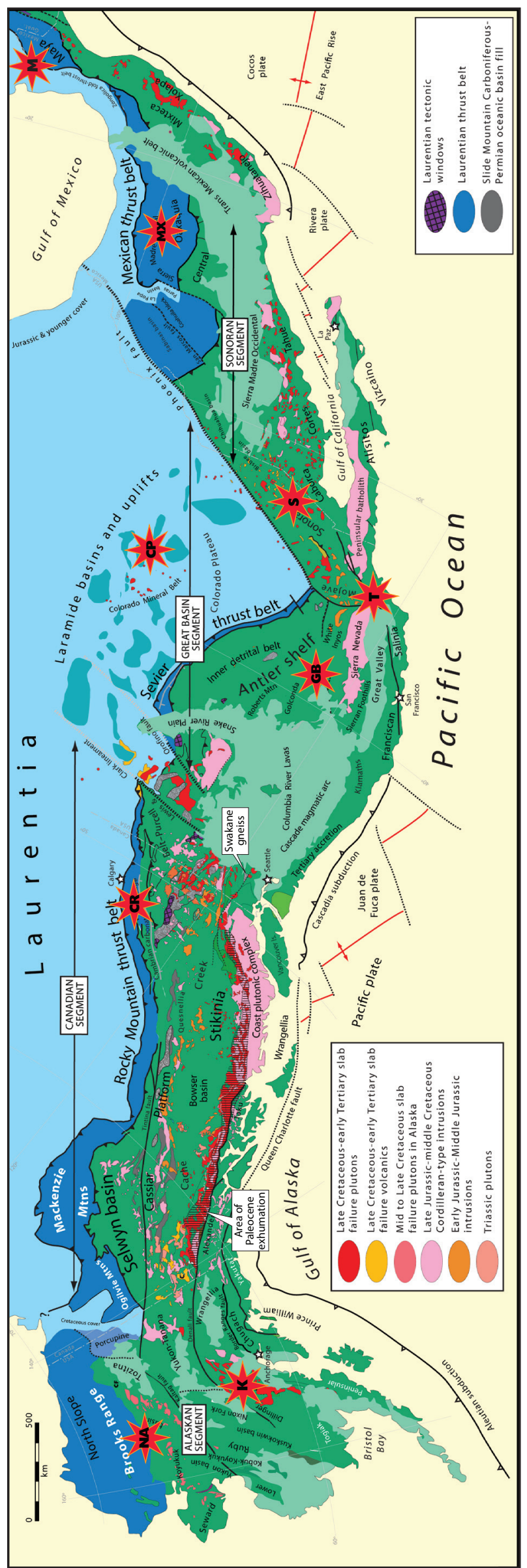

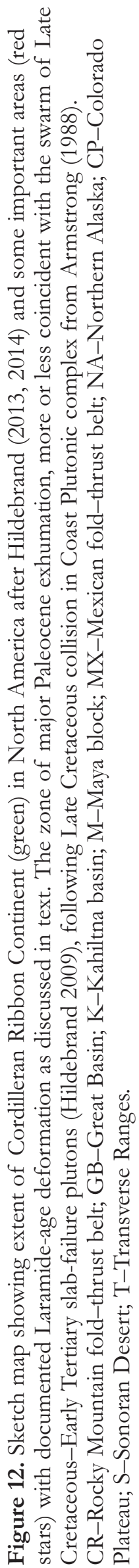

Peak-Alisitos arc of the Peninsular Ranges batholith - built upon a varied basement, ranging in age from Proterozoic to Jurassic (Shaw et al. 2014; Premo et al. 2014; Kistler et al. 2014), and torn from the western margin of the ribbon continent at about $140 \mathrm{Ma}$ (Lawton and McMillan 1999; Mauel et al. 2011; Peryam et al. 2012) - collided with a west-facing Lower Cretaceous carbonate platform, known as the Guerrero-Morelos platform in the south and the Sonoran shelf in the north (LaPierre et al. 1992; Monod et al. 1994; González-Léon et al. 2008). Because the basement within the arc terrane contained fragments of crust, such as the Antler platform and Caborca terrane (Ketner 1986; Gastil et al. 1991; Stewart 2005; Hildebrand 2009, 2013; Premo et al. 2010), derived from the ribbon continent, and ultimately from the 'lost' SW corner of North America, possibly during the transition from Pangea B to A (Irving 1977; Kent and Muttoni 2003; Irving 2004), make arguments tying the Guerrero superterrane to North America prior to the Laramide non-definitive. Terranes derived from this part of Laurentia should contain large quantities of Grenville age zircon grains reflecting their proximity to that belt, which was rich in Grenvillian basement (Hoffman 1989).

Returning to the summary of the Laramide event we note that to the south of Guerrero superterrane sector, lies the Zongolica fold-thrust belt (Figure 12), which involved thrusting of deeper water sedimentary rocks eastward over the reefal carbonatedominated Cordoba platform during the Santonian-Campanian (NietoSamaniego et al. 2006). In the Cuicateco terrane of southern Mexico, Maastrichtian schist, greenstone, gabbro, and serpentinite were thrust eastward over red beds of the Maya terrane during the latest Cretaceous-Paleocene (Pérez-Gutiérrez et al. 2009). At the southern end of the Maya block (Figure 12), a west-facing carbonate-dominated platform sitting on basement of the Maya block was drowned during the uppermost Campanian, buried by orogenic flysch during the Maastrichtian-Danian (Fourcade et al. 1994), and overthrust by ultramafic nappes. Rocks of the lower plate crystalline basement 
were metamorphosed to eclogite at 76 $\mathrm{Ma}$, which implies that part of the North American margin was subducted to a depth greater than $60 \mathrm{~km}$ at about that time and exhumed to amphibolite grade a million years later (Martens et al. 2012), presumably by slab failure.

Even farther south, in the rotated Chortis block, Rogers et al. (2007) documented a Late Cretaceous belt of southeast-dipping imbricate thrusts, which they interpreted to represent the accretion of the Caribbean arc system to the Chortis block (see also Pindell et al. 2005; Pindell and Kennan 2009; Ratschbacher et al. 2009). The arc-bearing block continues through its diachronous collision zone with the Bahamian Bank of North America represented on Cuba and Hispaniola, through the Virgin Islands (Schrecengost 2010) to its still active Antillian segment before reaching northern South America, where it was diachronously deformed along the coastline from west to east (Ostos et al. 2005). That the Antillean arc is part of the Great Arc is supported by the presence of Jurassic oceanic basement and chert at La Desirade (Mattinson et al. 2008; Montgomery and Kerr 2009).

Overall, the Laramide event was more or less synchronous from Alaska to Tierra del Fuego and, based on the mantle tomography and eastward vergence of thrusts, it is inferred that the Americas were the lower plate in a collision with an arc-bearing block, interpreted for North America as a more or less continuous ribbon continent (Johnston 2001, 2008; Moores et al. 2002; Hildebrand 2009, 2013). Adding the South American sector to it makes it one of the longest recognized orogenic belts of any age. The alternative hypothesis for magmatic shutdown and upper plate thrusting, that of an eastward-dipping flat slab carrying high-standing buoyant plateaux and ridges (Gutscher et al. 2000; von Huene and Ranero 2009), is simply unavailable as a viable mechanism over the strike-length observed.

Based on the ages of arc magmatism within it, the bulk of the ribbon continent was amalgamated during the Jurassic at around the time when, or just after, the Pacific plates formed (Hildebrand 2013). Thus, we suspect that the ribbon continent may have

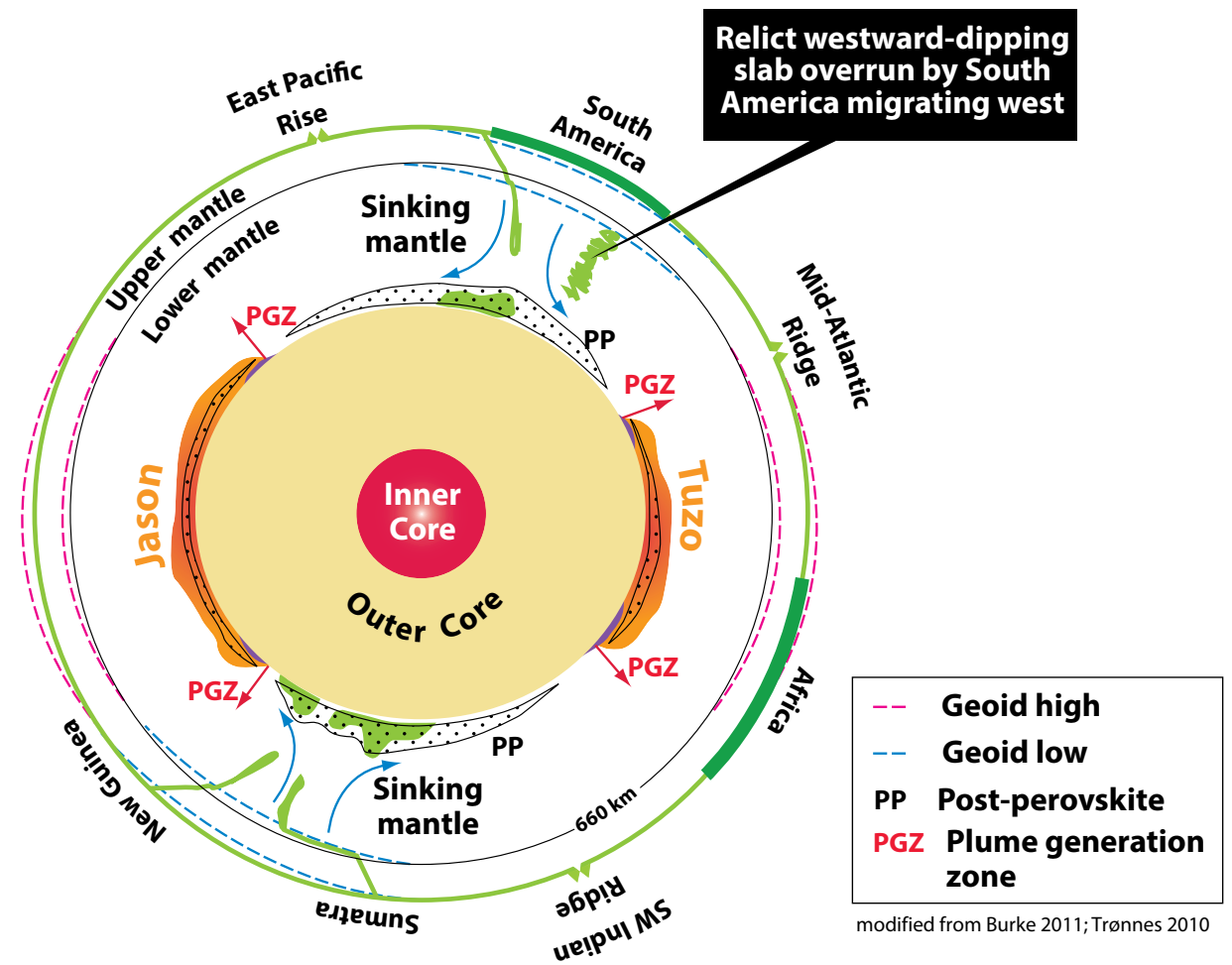

Figure 13. This model presented here is testable by mantle tomography, for if correct there should be a relict vertical slab wall beneath eastern South America and the western South Atlantic, just as exists beneath eastern North America. The occurrence of Late Cretaceous-Early Tertiary accretion by westward subduction over the length of both North and South America, and its composite nature, suggest that the Cordilleran Ribbon Continent developed over a zone of major downwelling into the mantle where various blocks were swept together during the Mesozoic. We speculate that this lengthy subduction complex sat west of Tuzo and east of Jason, the two long lived zones of mantle upwelling, and separated the Panthalassic oceanic plates from the Pacific oceanic plates as shown in this equatorial section. Modified from Trønnes (2010) and Burke (2011).

formed the boundary between the Panthalassic and Pacific plates, which if true, means that the Laramide event represents the final demise of the Panthalassic Ocean. This implies that the dominant mode for the Panthalassic closure was subduction away from the Americas, as independently confirmed for North America by deep mantle tomography (Sigloch and Mihalynuk 2013). Easterly subduction beneath the continents began only once the Panthalassic lithosphere was consumed. The Antillean and Scotian arcs represent the only active relics of the westerly dipping subduction regime.

Our model for South America predicts that a mid-mantle vertical fast anomaly, comparable to that beneath eastern North America, and representing a west-dipping oceanic slab overrun by the continent as it migrated westward (Sigloch 2011; Sigloch and
Mihalynuk 2013), exists beneath eastern South America and the western South Atlantic. Modern mantle tomography should be able to resolve it.

The Cordilleran Ribbon Continent is a composite terrane that is composed of many disparate fragments, yet these fragments were amalgamated prior to terminal collision with the Americas during the Laramide event. This implies that the ribbon continent was assembled above a major zone of mantle down-welling. If Tuzo and Jason represent zones of longlived mantle upwelling (Burke and Torsvik 2004; Torsvik et al. 2008a, b; Burke 2011) then we surmise that the Cordilleran Ribbon Continent developed above a complementary zone of down-welling between the two and represents a first-order feature of Mesozoic Earth (Figure 13). 


\section{CONCLUSIONS}

1. Five to nine $\mathrm{km}$ of eastward-shoaling, volcanic and volcaniclastic rocks were deposited within the Huarmey-Cañete basin, mainly during the Albian, and then between 105 and $100 \mathrm{Ma}$ were deformed and intruded by syn- to post-kinematic mafic-intermediate magmas at $100 \mathrm{Ma}$.

2. The Huarmey-Cañete volcanicvolcaniclastic sequence (Casma Group) is interpreted to represent an arc that collided with an unknown block or terrane at 105-100 Ma. This block may have been the Salinian block of westcentral California.

3. Contemporaneously with, and immediately after, the collision, the area was intruded by calcic to alkaline gabbro, strike-parallel bimodal dyke swarms, and more siliceous plutons collectively interpreted as slab-failure magmatism.

4. During the Tithonian-Albian period of arc volcanism, the Late Albian folding, and emplacement of plutons and dykes of the 105-82 Ma Coastal batholith, the area presently located to the east and occupied by rocks of the West Peruvian basin formed a quiescent west-facing carbonate-clastic platform to basin succession without volcanic debris or lacunas. The incompatibility between the two basins indicates that the Huarmey arc-Coastal batholith and their Arequipa basement were exotic with respect to the West Peruvian basin.

5. The east-vergent thrusts and the lack of an arc on South America indicate that the Huarmey arcCoastal batholith-Arequipa block collided with South America at 77 $\pm 5 \mathrm{Ma}$ above a west-dipping subduction zone to form the east-vergent Marañon fold-thrust belt.

6. After collision an intense swarm of 73-71 Ma belt-parallel dykes followed closely by 72-62 Ma centred complexes and ring dykes intruded the collision zone and is interpreted as slab-failure magmatism.

7. Volcanism of the Calipuy Group postdated the thrusting and is interpreted to be the initial magmatism of eastward subduction, which started by about $53 \mathrm{Ma}$.

8. Similar temporal and spatial relations exist over the entire western Andes and we interpret them to indicate that a ribbon continent collided with western South America during the Late CretaceousEarly Tertiary above a west-dipping subduction zone. The model predicts that there is a vertical slab (fast zone) in the mid-mantle beneath eastern South America and the western South Atlantic, just as occurs beneath eastern North America (Sigloch 2011; Sigloch and Mihalynuk 2013).

9. The South American ribbon continent was part of a much longer composite ribbon that included the North American ribbon continent, Rubia, and the Antillean and Scotian arcs.

10. The composite nature of the Cordilleran Ribbon Continent, which spanned the hemisphere from north to south, likely formed along the boundary of the Panthalassic and Pacific oceanic plates at a zone of long-lived mantle downwelling into which arcs and terranes were swept and amalgamated throughout the Mesozoic.

11. Following collision of the Cordilleran Ribbon Continent with the still westward migrating Americas, the current regime of eastward subduction of Pacific plates beneath North and South America commenced.

\section{ACKNOWLEDGEMENTS}

Discussions with Paul Hoffman were helpful and we are especially pleased to contribute to this volume honouring him, as Hoffman has been a 40-year mentor and friend to the senior author.

For this South American study Eldridge Moores provided the inspiration to examine the geology there. Discussions with him were always encouraging and enlightening. Alexandre Zagorevski (GSC) provided positive input on a draft of the manuscript. The manuscript was reviewed by two anonymous reviewers and Adrian Pfiffner, whose review we found especially constructive. This paper is another in our line of self-funded studies.

\section{REFERENCES}

Åberg, G., Aguirre, L., Levi, B., and Nyström, J.O., 1984, Spreading-subsidence and generation of ensialic marginal basins: an example from the early Cretaceous of central Chile, in Kokelaar, B.P., and Howells, M.F., eds., Marginal Basin Geology: Volcanic and Associated Sedimentary and Tectonic Processes in Modern and Ancient Marginal Basins: Geological Society, London, Special Publications, v. 16, p. 185-193, http://dx.doi.org/10.1144/GSL.SP.19 84.016.01.14.

Allison, F.C., 1974, The type Alisitos formation (Cretaceous, Aptian-Albian) of Baja California and its bivalve fauna, in Gastil, G., and Lillegraven, J., eds., Geology of Peninsular California, AAPG-SEPM-SEG Pacific Section 49th Annual Meeting Field Trip Guidebook, p. 20- 59.

Allmendinger, R.W., Jordan, T.E., Kay, S.M., and Isacks, B.L., 1997, The evolution of the Altiplano-Puna plateau of the central Andes: Annual Review of Earth and Planetary Sciences, v. 25, p. 139-174, http://dx.doi.org/ 10.1146/annurev.earth.25.1.139.

Altamira-Areyán, A., 2009, The ribbon continent of northwestern South America: Unpublished PhD thesis, The University of Houston, Houston, TX, 193 p.

Alvarez, W., 1982, Geological evidence for the geographical pattern of mantle return flow and the driving mechanism of plate tectonics: Journal of Geophysical Research, v. 87, p. 6697-6710, http://dx.doi.org/ 10.1029/JB087iB08p06697.

Armstrong, R.L., 1988, Mesozoic and early Cenozoic magmatic evolution of the Canadian Cordillera, in Clark, S.P., Jr., Burchfiel, B.C., and Suppe, J., eds., Processes in Continental Lithospheric Deformation: Geological Society of America Special Papers, v. 218, p. 55-92, http://dx.doi.org/ 10.1130/SPE218-p55.

Arriagada, C., Cobbold, P.R., and Roperch, P., 2006, Salar de Atacama basin: A record of compressional tectonics in the central Andes since the mid-Cretaceous: Tectonics, v. 25, TC1008, http://dx.doi.org/10.1029/2004TC00 1770.

Atherton, M.P., and Ghani, A.A., 2002, Slab breakoff: A model for Caledonian late granite syn-collisional magmatism in the orthotectonic (metamorphic) zone of Scotland and Donegal, Ireland: Lithos, v. 62, p. 65-85, http://dx.doi.org/10.1016/S00244937(02)00111-1. 
Atherton, M.P., and Webb, S., 1989, Volcanic facies, structure, and geochemistry of the marginal basin rocks of central Peru: Journal of South American Earth Sciences, v. 2, p. 241-261, http://dx.doi.org/10.1016/08959811(89)90032-1.

Atherton, M.P., McCourt, W.J., Sanderson, L.M., and Taylor, W.P., 1979, The geochemical character of the segmented Peruvian Coastal Batholith and associated volcanics, in Atherton, M.P., and Tarney, J., eds., Origin of Granite Batholiths: Geochemical Evidence: Birkhäuser Boston, p. 45-64, http://dx.doi.org/10.1007/978-14684-0570-5_5.

Atherton, M.P., Pitcher, W. S., and Warden V., 1983, The Mesozoic marginal basin of central Peru: Nature, v. 305, p. 303-306, http://dx.doi.org/ 10.1038/305303a0.

Atherton, M.P., Warden, V., and Sanderson, L.M., 1985a, The Mesozoic marginal basin of central Peru: A geochemical study of within-plate-edge volcanism, in Pitcher, W.S., Atherton, M.P., Cobbing, E.J., and Beckinsale, R.B., eds., Magmatism at a Plate Edge: the Peruvian Andes: Blackie Halstead Press, Glasgow, p. 47-58, http://dx.doi.org/ 10.1007/978-1-4899-5820-4_6.

Atherton, M.P., Sanderson, L.M., Warden, V., and McCourt, W.J., 1985b, The volcanic cover: chemical composition and the origin of the magmas of the Calipuy Group, in Pitcher, W.S., Atherton, M.P., Cobbing, E.J., and Beckinsale, R.B., eds., Magmatism at a Plate Edge: the Peruvian Andes: Blackie Halstead Press, Glasgow, p. 273-284, http://dx.doi.org/10.1007/978-14899-5820-4_25.

Barker, P.F., Dalziel, I.W.D., and Storey, B.C., 1991, Tectonic development of the Scotia Arc region, in Tingey, R.J., ed., Geology of Antarctica: Oxford, Oxford University Press, p. 215-248.

Bateman, P.C., 1992, Plutonism in the Central Part of the Sierra Nevada Batholith: U.S. Geological Survey Professional Paper 1483, 186 p.

Burke, K., 2011, Plate tectonics, the Wilson cycle, and mantle plumes: Geodynamics from the top: Annual Reviews, Earth and Planetary Sciences, v. 39, p. 1-29, http://dx.doi.org/ 10.1146/annurev-earth-040809152521.

Burke, K., and Torsvik, T.H., 2004, Derivation of large igneous provinces of the past 200 million years from long-term heterogeneities in the deep mantle: Earth and Planetary Science Letters, v. 227, p. 531-538, http://dx.doi.org/ 10.1016/j.eps1.2004.09.015.

Busby, C., 2012, Extensional and transtensional continental arc basins: Case studies from the southwestern U.S. and Mexico, in Busby, C., and Azor, A., eds., Recent Advances in Tectonics of Sedimentary Basins: London, Wiley-Blackwell, p. 382-404.

Busby, C., Adams, B.F., Mattinson, J., and Deoreo, S., 2006, View of an intact oceanic arc, from surficial to mesozonal levels: Cretaceous Alisitos arc, Baja California: Journal of Volcanology and Geothermal Research, v. 149, p. 1-46, http://dx.doi.org/ 10.1016/j.jvolgeores.2005.06.009.

Busby-Spera, C.J., 1988, Speculative tectonic model for the early Mesozoic arc of the southwest Cordilleran United States: Geology, v. 16, p. 1121-1125, http://dx.doi.org/10.1130/00917613(1988)016<1121:STMFTE>2.3.C $\mathrm{O} ; 2$.

Busch, D.A., and Gavela, A., 1978, Stratigraphy and structure of Chicontepec turbidites, southeastern Tampico-Misantla basin, Mexico: American Association of Petroleum Geologists Bulletin, v. 62, p. 235-246.

Bussell, M.A., 1985, The centered complex of the Rio Huaura: a study of magma mixing and differentiation in highlevel magma chambers, in Pitcher, W.S., Atherton, M.P., Cobbing, E.J., and Beckinsale, R.B., eds., Magmatism at a Plate Edge: the Peruvian Andes: Blackie Halstead Press, Glasgow, p. 128-155, http:/ /dx.doi.org/ 10.1007/978-1-4899-5820-4_13.

Bussell, M.A., Pitcher, W.S., and Wilson, P.A., 1976, Ring complexes of the Peruvian Coastal Batholith: a longstanding subvolcanic regime: Canadian Journal of Earth Sciences, v. 13, p. 1020-1030, http://dx.doi.org/10.1139/e76-105.

Camilleri, P., Yonkee, A., Coogan, J., DeCelles, P., McGrew, A., and Wells, M., 1997, Hinterland to foreland transect through the Sevier Orogen, north-east Nevada to north central Utah: Structural style, metamorphism, and kinematic history of a large contractional orogenic wedge, in Link, P.K., and Kowallis, B.J., eds., Proterozoic to Recent Stratigraphy, Tectonics, and Volcanology, Utah, Nevada, Southern Idaho and Central Mexico: Provo, Brigham Young University Geology Studies, v. 42, p. 297-309.

Cardona, A., Cordani, U.G., Ruiz, J., Valencia, V.A., Armstrong, R., Chew, D., Nutman, A., and Sanchez, A.W., 2009, $\mathrm{U}-\mathrm{Pb}$ zircon geochronology and $\mathrm{Nd}$ isotopic signatures of the pre-Meso- zoic metamorphic basement of the Eastern Peruvian Andes: Growth and provenance of a Late Neoproterozoic to Carboniferous accretionary orogen on the Northwest margin of Gondwana: The Journal of Geology, v. 117, p. $285-305$, http://dx.doi.org/10.1086/597472.

Casquet, C., Fanning, C.M., Galindo, C., Pankhurst, R.J., Rapela, C.W., and Torres, P., 2010, The Arequipa Massif of Peru: New SHRIMP and isotope constraints on a Paleoproterozoic inlier in the Grenvillian orogen: Journal of South American Earth Sciences, v. 29, p. 128-142, http://dx.doi.org/ 10.1016/j.jsames.2009.08.009.

Castroviejo, R., Rodrigues, J.F., Acosta, J., Pereira, E., Romero, D., Quispe, J., and Espí, J.A., 2009, Geología de las ultramafitas pre-andinas de Tapo y Acobamba, Tarma, Cordillera Oriental del Peru: Sociedad Geológica Espaola, Geogaceta, Madrid, v. 46, p. 7-10.

Castroviejo, R., Macharé, J., Castro, P., Pereira, E., Rodrigues, J.F., Tassinari, C.G., Willner, A., and Acosta, J., 2010, Significado de las ofiolitas neoproterozoicas de la Cordillera Oriental del Perú $\left(9^{\circ} 30^{\prime}-11^{\circ} 30^{\prime}\right)$, Sociedad Geológica del Perú, 15th Congreso Peruano de Geología, Publicación Especial 9, Cusco, p. 51-53.

Catuneanu, O., Sweet, A.R., and Miall, A.D., 2000, Reciprocal stratigraphy of the Campanian-Paleocene Western Interior of North America: Sedimentary Geology, v. 134, p. 235-255, http://dx.doi.org/10.1016/S00370738(00)00045-2.

Centeno-García, E., Guerrero-Suastegui, M., and Talavera-Mendoza, O., 2008, The Guerrero Composite Terrane of western Mexico: Collision and subsequent rifting in a supra-subduction zone, in Draut, A., Clift, P.D., and Scholl, D.W., eds., Formation and Applications of the Sedimentary Record in Arc Collision Zones: Geological Society of America Special Papers, v. 436, p. 279-308, http://dx.doi.org/10.1130/2008.2436 (13).

Centeno-García, E., Busby, C., Busby, M., and Gehrels, G., 2011, Evolution of the Guerrero composite terrane along the Mexican margin, from extensional fringing arc to contractional continental arc: Geological Society of America Bulletin, v. 123, p. 1776-1797, http://dx.doi.org/10.1130/B30057.1.

Champion, D.E., Howell, D.G., and Gromme, C.S., 1984, Paleomagnetic and geologic data indicating $2500 \mathrm{~km}$ of northward displacement for the 
Salinian and related terranes, California: Journal of Geophysical Research, v. 89 , p. $7736-7752$,

http://dx.doi.org/10.1029/JB089iB09 p07736.

Chapman, A.D., Ducea, M.N., Kidder, S., and Petrescu, L., 2014, Geochemical constraints on the petrogenesis of the Salinian arc, central California: Implications for the origin of intermediate magmas: Lithos, v. 200-201, p.

126-141, http://dx.doi.org/ 10.1016/j.lithos.2014.04.011.

Chappell, B.W., and Stephens, W.E., 1988, Origin of infracrustal (I-type) granite magmas: Transactions of the Royal Society of Edinburgh: Earth Sciences, v. 79, p. 71-86, http://dx.doi.org/ 10.1017/S0263593300014139.

Chew, D.M., Schaltegger, U., Košler, J., Whitehouse, M.J., Gutjahr, M., Spikings, R.A., and Miškovíc, A., 2007, $\mathrm{U}-\mathrm{Pb}$ geochronologic evidence for the evolution of the Gondwanan margin of the north-central Andes: Geological Society of America Bulletin, v. 119, p. 697-711, http://dx.doi.org/10.1130/B26080.1.

Clinkenbeard, J.P., and Walawender, M.J., 1989, Mineralogy of the La Posta pluton: Implications for the origin of zoned plutons in the eastern Peninsular Ranges batholith, southern and Baja California: The American Mineralogist, v. 74, p. 1258-1269.

Cloos, M., Sapiie, B., van Ufford, A.Q., Weiland, R.J., Warren, P.Q., and McMahon, T.P., 2005, Collisional Delamination in New Guinea: The Geotectonics of Subducting Slab Breakoff: Geological Society of America Special Papers, v. 400, 51 p., http://dx.doi.org/10.1130/2005.2400.

Cobbing, E.J., 1976, The geosynclinal pair at the continental margin of Peru: Tectonophysics, v. 36, p. 157-165, http://dx.doi.org/10.1016/00401951(76)90013-5.

Cobbing, E.J., 1978, The Andean geosyncline in Peru, and its distinction from Alpine geosynclines: Journal of the Geological Society, v. 135, p. 207-218, http://dx.doi.org/10.1144/gsigs.135.2. 0207.

Cobbing, E.J., 1985, The tectonic setting of the Peruvian Andes, in Pitcher, W.S., Atherton, M.P., Cobbing, E.J., and Beckinsale, R.B., eds., Magmatism at a Plate Edge: the Peruvian Andes: Blackie Halstead Press, Glasgow, 3-12, http://dx.doi.org/10.1007/978-14899-5820-4_1.

Cobbing, E.J., and Pitcher, W.S., 1972a, The Coastal Batholith of central Peru: Journal of the Geological Society, v.
128, p. 421-454, http://dx.doi.org/ 10.1144/gsigs.128.5.0421.

Cobbing, E.J., and Pitcher, W.S., 1972b, Plate tectonics and the Peruvian Andes: Nature Physical Science, v. 240, p. 51-53, http://dx.doi.org/ 10.1038/physci240051a0.

Cobbing, E.J., and Pitcher, W.S., 1983, Andean plutonism in Peru and its relationship to volcanism and metallogenesis at a segmented plate edge, in Roddick, J.A., ed., Circum-Pacific Plutonic Terranes: Geological Society of America Memoirs, v. 159, p. 277-292, http://dx.doi.org/10.1130/MEM159p277.

Cobbing, E.J., Pitcher, W.S., Wilson, J.J., Baldock, J.W., Taylor, W.P., McCourt, W., and Snelling, N.J., 1981, The geology of the Western Cordillera of northern Peru: London, Institute of Geological Sciences, Overseas Memoir 5, $143 \mathrm{p}$.

Cobbold, P.R., and Rossello, E.A., 2003, Aptian to Recent compressional deformation, foothills of the Neuquén Basin, Argentina: Marine and Petroleum Geology, v. 20, p. 429-443, http://dx.doi.org/10.1016/S02648172(03)00077-1.

Coleman, D.S., and Glazner, A.F., 1998, The Sierra Crest magmatic event: Rapid formation of juvenile crust during the Late Cretaceous in California, in Ernst, W.G., and Nelson, C.A., eds., Integrated Earth and Environmental Evolution of the Southwestern United States: The Clarence A. Hall Jr. Volume: Columbia, Maryland, Bellwether Publishing for the Geological Society of America, p. 253-272.

Couch, R., Whitsett, R., Huehn, B., and Briceno-Guarupe, L., 1981, Structures of the continental margin of Peru and Chile, in Kulm, L.V.D., Dymond, J., Dasch, E.J., and Hussong, D.M., eds., Nazca Plate: Crustal Formation and Andean Convergence: Bulletin of the Geological Society of America Memoirs, v. 154 , p. $703-726$, http://dx.doi.org/10.1130/MEM154p703.

Dalziel, I.W.D., de Wit, M.J., and Palmer, K.F., 1974, Fossil marginal basin in the southern Andes: Nature, v. 250, p. 291-294, http://dx.doi.org/10.1038/250291a0.

Davies, J.H., 2002, Breaking plates: Nature, v. 418 , p. $736-737$, http://dx.doi.org/10.1038/418736a.

Davies, J.H., and von Blanckenburg, F., 1995, Slab break-off: A model of lithosphere detachment and its test in the magmatism and deformation of collisional orogens: Earth and Planetary
Science Letters, v. 129, p. 85-102, http://dx.doi.org/10.1016/0012821X(94)00237-S.

DeCelles, P.G., and Coogan, J.C., 2006, Regional structure and kinematic history of the Sevier fold-and-thrust belt, central Utah: Geological Society of America Bulletin, v. 118, p. 841-864, http://dx.doi.org/10.1130/B25759.1.

DeCelles, P.G., and Horton, B.K., 2003, Early to middle Tertiary foreland basin development and the history of Andean crustal shortening in Bolivia: Geological Society of America Bulletin, v. 115 , p. 58-77, http:/ /dx.doi.org/10.1130/00167606(2003)115<0058:ETMTFB>2.0.C $\mathrm{O} ; 2$.

DeCelles, P.G., Ducea, M.N., Kapp, P., and Zandt, G., 2009, Cyclicity in Cordilleran orogenic systems: Nature Geoscience, v. 2, p. 251-257, http://dx.doi.org/10 .1038/ngeo469.

de Haller, A., Corfu, F., Fontboté, L., Schaltegger, U., Barra, F., Chiaradia, M., Frank, M., and Zúñiga Alvarado, J., 2006, Geology, geochronology, and $\mathrm{Hf}$ and $\mathrm{Pb}$ isotope data of the RaúlCondestable iron oxide-copper-gold deposit, central coast of Peru: Economic Geology, v. 101, p. 281-310, http://dx.doi.org/10.2113/gsecongeo.101.2.281.

Dick, H.J.B., Natland, J.H., and Ildefonse, B., 2006, Past and future impact of deep drilling in the oceanic crust and mantle: Oceanography, v. 19, p. 72-80, http://dx.doi.org/10.5670/oceanog.20 06.06 .

Dickinson, W.R., Klute, M.A., Hayes, M.J., Janecke, S.U., Lundin, E.R., McKittrick, M.A., and Olivares, M.D., 1988, Paleogeographic and paleotectonic setting of Laramide sedimentary basins in the central Rocky Mountain region: Geological Society of America Bulletin, v. 100, p. 1023-1039, http:/ /dx.doi.org/10.1130/00167606(1988)100<1023:PAPSOL > 2.3.C $\mathrm{O} ; 2$.

Doubrovine, P.V., Steinberger, B., and Torsvik, T.H., 2012, Absolute plate motions in a reference frame defined by moving hot spots in the Pacific, Atlantic, and Indian oceans: Journal of Geophysical Research, v. 117, B09101, http:/ /dx.doi.org/10.1029/2011JB009 072.

Ducea, M., 2001, The California arc: Thick granitic batholiths, eclogitic residues, lithospheric-scale thrusting, and magmatic flare-ups: GSA Today, v. 11, no. 11, p. 4-10.

Duretz, T., Schmalholz, S.M., and Gerya, T.V., 2012, Dynamics of slab detach- 
ment: Geochemistry, Geophysics, Geosystems, v. 13, Q03020, http://dx.doi.org/10.1029/2011GC00 4024.

Eguiliz de Antuñano, S., Aranda Garcia, M., and Marrett, R., 2000, Tectónica de la Sierra Madre Oriental, Mexico: Boletin de la Sociedad Geologica Mexicana, v. 53, p. 1-26.

Elder, W.P., and Saul, L.R., 1993, Paleogeographical implications of molluscan assemblages in the Upper Cretaceous Pigeon Point Formation, California, in Dunne, G., and McDougall, K., eds., Mesozoic Paleogeography of the Western United States-II: Pacific Section, Society of Economic Paleontologists and Mineralogists, Book 71, p. 171-186.

Ellison, R.A., Klinck, B.A., and Hawkins, M.P., 1989, Deformation events in the Andean orogenic cycle in the Altiplano and Western Cordillera, southern Peru: Journal of South American Earth Sciences, v. 2, p. 263-276, http:/ /dx.doi.org/10.1016/08959811(89)90033-3.

Feininger, T., 1980, Eclogite and related high-pressure regional metamorphic rocks from the Andes of Ecuador: Journal of Petrology, v. 21, p. 107-140, http://dx.doi.org/ 10.1093/petrology/21.1.107.

Feininger, T., 1987, Allochthonous terranes in the Andes of Ecuador and northwestern Peru: Canadian Journal of Earth Sciences, v. 24, p. 266-278, http://dx.doi.org/10.1139/e87-028.

Fermor, P.R., and Moffat, I.W., 1992, Tectonics and structure of the Western Canada foreland basin, in MacQueen, R.W., and Leckie, D.A., eds., Foreland Basins and Fold Belts: American Association of Petroleum Geologists Memoir 55, p. 81-105.

Fife, D.L., Minch, J.A., and Crampton, P.J., 1967, Late Jurassic age of the Santiago Peak volcanics, California: Geological Society of America Bulletin, v. 78, p, 299-304, http:/dx.doi.org/ 10.1130/0016-7606(1967)78 [299:LJAOTS]2.0.CO;2.

Fitch, T.J., 1972, Plate convergence, transcurrent faults, and internal deformation adjacent to southeast Asia and the western Pacific: Journal of Geophysical Research, v. 77, p. 4432-4460, http://dx.doi.org/10.1029/JB077i023 p04432.

Fitz-Díaz, E., Tolson, G., Hudleston, P., Bolaños-Rodríguez, D., Ortega-Flores, B., and Vásquez Serrano, A., 2012, The role of folding in the development of the Mexican fold-and-thrust belt: Geosphere, v. 8, p. 931-949, http:/ /dx.doi.org/10.1130/ GES00759.1.

Fourcade, E., Mendez, J., Azema, J., Bellier, J., Cros, P., Michaud, F., Carballo, M., and Villagran, J.C., 1994, Dating of the settling and drowning of the carbonate platform, and of the overthrusting of the ophiolites on the Maya Block during the Mesozoic (Guatemala): Newsletters on Stratigraphy, v. 30, p. 33-43.

Frost, B.R., and Frost, C.D., 2008, A geochemical classification for feldspathic igneous rocks: Journal of Petrology, v. 49, p. 1955-1969, http://dx.doi.org/ 10.1093/petrology/egn054.

Frost, B.R., Barnes, C.G., Collins, W.J., Arculus, R.J., Ellis, D.J., and Frost, C.D., 2001, A geochemical classification for granitic rocks: Journal of Petrology, v. 42, p. 2033-2048, http:/ /dx.doi.org/10.1093/petrology/42.11.2033.

Garrett, S.W., Renner, R.G.B., Jones, J.A., and McGibbon, K.J., 1987, Continental magnetic anomalies and the evolution of the Scotia arc: Earth and Planetary Science Letters, v. 81, p. 273-281, http://dx.doi.org/ 10.1016/0012 -821X(87)90163-4.

Gastil, R.G., Miller, R., Anderson, P., Crocker, J., Campbell, M., Buch, P., Lothringer, C., Leier-Engelhardt, P., DeLattre, M., Hoobs, J., and RoldánQuintana, J., 1991, The relation between the Paleozoic strata on opposite sides of the Gulf of California, in Pérez-Segura, E., and Jacques-Ayala, C., eds., Studies of Sonoran geology: Geological Society of America Special Papers, v. 254, p. 7-18, http://dx.doi.org/10.1130/SPE254p7.

Gehrels, G., Rusmore, M., Woodsworth, G., Crawford, M., Andronicos, C., Hollister, L., Patchett, J., Ducea, M., Butler, R., Klepeis, K., Davidson, C., Friedman, R., Haggart, J., Mahoney, B., Crawford, W., Pearson, D., and Girardi, J., 2009, U-Th-Pb geochronology of the Coast Mountains batholith in north-coastal British Columbia: Constraints on age and tectonic evolution: Geological Society of America Bulletin, v. 121, p. 1341-1361, http://dx.doi.org/10.1130/B26404.1.

Ghiglione, M.C., Quinteros, J., Yagupsky, D., Bonillo-Martínez, P., Hlebszevtich, J., Ramos, V.A., Vergani, G., Figueroa, D., Quesada, S., and Zapata, T., 2010, Structure and tectonic history of the foreland basins of southernmost South America: Journal of South American Earth Sciences, v. 29, p.
262-277, http:/ /dx.doi.org/

10.1016/j.jsames.2009.07.006.

Gîrbacea, R., and Frisch, W., 1998, Slab in the wrong place: Lower lithospheric mantle delamination in the last stage of the Eastern Carpathian subduction retreat: Geology, v. 26, p. 611-614, http://dx.doi.org/10.1130/00917613(1998)026<0611:SITWPL>2.3.C $\mathrm{O} ; 2$.

González-Léon, C.M., Scott, R.W., Löser, H., Lawton, T.F., Robert, E., and Valencia, V.A., 2008, Upper AptianLower Albian Mural Formation: stratigraphy, biostratigraphy and depositional cycles on the Sonoran shelf, northern México: Cretaceous Research, v. 29, p. 249-266, http://dx.doi.org/10.1016/j.cretres.2007.06.001.

Grand, S.P., van der Hilst, R.D., and Widiyantoro, S., 1997, Global seismic tomography: A snapshot of convection in the Earth: GSA Today, v. 7, no. 4, p. 1-7.

Gutscher, M.-A., Spakman, W., Bijwaard, H., and Engdahl, E.R., 2000, Geodynamics of flat subduction: Seismicity and tomographic constraints from the Andean margin: Tectonics, v. 19, p. 814-833, http://dx.doi.org/ 10.1029/1999TC001152.

Hagstrum, J.T., McWilliams, M., Howell, D.G., and Grommé, S., 1985, Mesozoic paleomagnetism and northward translation of the Baja California Peninsula: Geological Society of America Bulletin, v. 96, p. 1077-1090, http://dx.doi.org/10.1130/00167606(1985)96<1077:MPANTO>2.0.C $\mathrm{O} ; 2$.

Hamilton, W.B., 1969a, Mesozoic California and the underflow of Pacific mantle: Geological Society of America Bulletin, v. 80, p. 2409-2430, http://dx.doi.org/10.1130/00167606(1969)80[2409:MCATUO]2.0.CO; 2.

Hamilton, W.B., 1969b, The volcanic central Andes, a modern model for the Cretaceous batholiths and tectonics of western North America: Oregon Department of Geology and Mineral Industries Bulletin, v. 65, p. 175-184.

Hennings, P.H., 1994, Structural transect of the southern Chihuahua Fold Belt between Ojinaga and Aldama, Chihuahua, Mexico: Tectonics, v. 13, p. 1445-1460, http://dx.doi.org/ 10.1029/94TC00800.

Hildebrand, R.S., 2009, Did westward subduction cause Cretaceous-Tertiary Orogeny in the North American Cordillera?: Geological Society of America Special Papers, v. 457, 71 p., 
http://dx.doi.org/10.1130/2009.2457.

Hildebrand, R.S., 2013, Mesozoic Assem-

bly of the North American Cordillera: Geological Society of America Special Papers, v. 495, 169 p.,

http://dx.doi.org/10.1130/978081372 4959.

Hildebrand, R.S., 2014, Geology, mantle tomography, and inclination corrected paleogeographic trajectories support westward subduction during Cretaceous orogenesis in the North American Cordillera: Geoscience Canada, v. 41, p. 207-224, http://dx.doi.org/ 10.12789/geocanj.2014.41.032.

Hildebrand, R.S., and Bowring, S.A., 1984, Continental intra-arc depressions: A nonextensional model for their origin, with a Proterozoic example from Wopmay orogen: Geology, v. 12, p. 73-77, http://dx.doi.org/ 10.1130/0091-7613(1984)12 $<78$ :WRAOEO>2.0.CO;2.

Hoffman, P.F., 1989, Precambrian geology and tectonic history of North America, in Bally, A.W., and Palmer, A.R., eds., The Geology of North America-An Overview: Boulder, Colorado, Geological Society of America, Geology of North America, v. A, p. 447-511.

Howell, J.A., Schwartz, E., Spalletti, L.A., and Veiga, G.D., 2005, The Neuquén Basin: an overview, in Veiga, G.D., Spalletti, L.A., Howell, J.A., and Schwartz, E., eds., The Neuquén Basin, Argentina: A Case Study in Sequence Stratigraphy and Basin Dynamics: Geological Society, London, Special Publications, v. 252, p. 1-14, http://dx.doi.org/10.1144/GSL.SP.20 05.252.01.01.

Hults, C.P., Wilson, F.H., Donelick, R.A., and O'Sullivan, P.B., 2013, Two flysch belts having distinctly different provenance suggest no stratigraphic link between the Wrangellia composite terrane and the paleo-Alaskan margin: Lithosphere, v. 5, p. 575-594, http://dx.doi.org/10.1130/L310.1.

Irving, E., 1977, Drift of the major continental blocks since the Devonian: Nature, v. 270, p. 304-309, http://dx.doi.org/10.1038/270304a0.

Irving, E., 2004, The case for Pangea B, and the Intra-Pangean megashear, in Channell, J.E.T., Kent, D.V., Lowrie, W., and Meert, J.G., eds., Timescales of the Paleomagnetic Field: American Geophysical Union, Geophysical Monograph Series, v. 145, p. 13-27.

Isacks, B., and Molnar P., 1969, Mantle earthquake mechanisms and the sinking of the lithosphere: Nature, v. 223, p. 1121-1124, http://dx.doi.org/ 10.1038/2231121a0.

Jacobson, C.E., Grove, M., Vucic, A., Pedrick, J.N., and Ebert, K.A., 2007, Exhumation of the Orocopia Schist and associated rocks of southeastern California: Relative roles of erosion, synsubduction tectonic denudation, and middle Cenozoic extension, in Cloos, M., Carlson, W.D., Gilbert, M.C., Liou, J.G., and Sorensen, S.S., eds., Convergent Margin Terranes and Associated Regions: A Tribute to W.G. Ernst: Geological Society of America Special Papers, v. 419, p. 1-37, http://dx.doi.org/10.1130/2007.2419 (01).

Jaillard, E., and Soler, P., 1996, Cretaceous to early Paleogene tectonic evolution of the northern Central Andes $\left(0-18^{\circ} \mathrm{S}\right)$ and its relations to geodynamics: Tectonophysics, v. 259, p. 41-53, http:/ /dx.doi.org/ 10.1016/0040-1951(95)00107-7. Jaillard, E., Laubacher, G., Bengston, P., Dhondt, A.V., and Bulot, L.G., 1999, Stratigraphy and evolution of the Cretaceous forearc Celica-Lancones basin of southwestern Ecuador: Journal of South American Earth Sciences, v. 12, p. 51-68, http://dx.doi.org/ 10.1016/S0895-9811(99)00006-1.

Jaillard, E., Lapierre, H., Ordoñez, M., Álava, J.T., Amórtegui, A., and Vanmelle, J., 2009, Accreted oceanic terranes in Ecuador: southern edge of the Caribbean Plate?, in James, K.H., Lorente, M.A., and Pindell, J.L., eds., The Origin and Evolution of the Carribean Plate: Geological Society, London, Special Publications, v. 328; p. 469-485, http://dx.doi.org/10.1144/SP328.19.

Johnston, S.T., 2001, The great Alaskan terrane wreck: reconciliation of paleomagnetic and geological data in the northern Cordillera: Earth and Planetary Science Letters, v. 193, p. 259-272, http://dx.doi.org/ 10.1016/S0012-821X(01)00516-7.

Johnston, S.T., 2008, The Cordilleran ribbon continent of North America: Annual Review of Earth and Planetary Sciences, v. 36, p. 495-530, http://dx.doi.org/10.1146/annurev.ea rth.36.031207.124331.

Jones, P.R., III, 1981, Crustal structures of the Peru continental margin and adjacent Nazca Plate, $9^{\circ} \mathrm{S}$ latitude, in Kulm, L.V.D., Dymond, J., Dasch, E.J., and Hussong, D.M., eds., Nazca Plate: Crustal Formation and Andean Convergence: Geological Society of America Memoirs, v. 154, p. 423-444, http://dx.doi.org/10.1130/MEM154p423.
Kay, S.M., and Mpodozis, C., 2002, Magmatism as a probe to the Neogene shallowing of the Nazca plate beneath the modern Chilean flat-slab: Journal of South American Earth Sciences, v. 15, p. 39-57.

Kennan, L., and Pindell, J.L., 2009, Dextral shear, terrane accretion and basin formation in the Northern Andes: best explained by interaction with a Pacificderived Caribbean Plate?, in James, K.H., Lorente, M.A., and Pindell, J.L., eds., The Origin and Evolution of the Caribbean Plate: Geological Society, London, Special Publications, v. 328, p. 487-531, http://dx.doi.org/10.1144/SP328.20.

Kent, D.V., and Irving, E., 2010, Influence of inclination error in sedimentary rocks on the Triassic and Jurassic apparent pole wander path for North America and implications for Cordilleran tectonics: Journal of Geophysical Research, v. 115, B10103, http://dx.doi.org/10.1029/2009JB007 205.

Kent, D.V., and Muttoni, G., 2003, Mobility of Pangea: Implications for Late Paleozoic and Early Mesozoic paleoclimate, in Le'Tourneau, P.M., and Olsen, P.E., eds., The Great Rift Valleys of Pangea in Eastern North America, Volume 1: Tectonics, Structure, and Volcanism: Columbia University Press, New York, p. 11-20.

Ketner, K.B., 1986, Eureka Quartzite in Mexico? - Tectonic implications: Geology, v. 14, p. 1027-1030, http://dx.doi.org/10.1130/00917613(1986)14<1027:EQIMI>2.0.CO; 2.

Kidder, S., Ducea, M., Gehrels, G., Patchett, P.J., and Vervoort, J., 2003, Tectonic and magmatic development of the Salinian Coast Ridge Belt, California: Tectonics, v. 22, 1058, http://dx.doi.org/10.1029/2002TC00 1409.

Kimbrough, D.L., Smith, D.P., Mahoney, J.B., Moore, T.E., Grove, M., Gastil, R.G., Ortega-Rivera, A., and Fanning, C.M., 2001, Forearc-basin sedimentary response to rapid Late Cretaceous batholith emplacement in the Peninsular Ranges of southern and Baja California: Geology, v. 29, p. 491-494, http:/ / dx.doi.org/10.1130/00917613(2001)029<0491:FBSRTR>2.0.C $\mathrm{O} ; 2$.

Kistler, R.W., and Champion, D.E., 2001, $\mathrm{Rb}-\mathrm{Sr}$ whole-rock and mineral ages, $\mathrm{K}-\mathrm{Ar},{ }^{40} \mathrm{Ar} /{ }^{39} \mathrm{Ar}$, and $\mathrm{U}-\mathrm{Pb}$ mineral ages, and strontium, lead, neodymium, and oxygen isotopic compositions for granitic rocks from the Salinian Com- 
posite Terrane, California: U.S. Geological Survey Open-File Report 01453, 84 p.

Kistler, R.W., Wooden, J.L., Premo, W.R., and Morton, D.M., 2014, $\mathrm{Pb}-\mathrm{Sr}-\mathrm{Nd}-\mathrm{O}$ isotopic characterization of Mesozoic rocks throughout the northern end of the Peninsular Ranges batholith: Isotopic evidence for the magmatic evolution of oceanic arc-continental margin accretion during the Late Cretaceous of southern California, in Morton, D.M., and Miller, F.K., eds., Peninsular Ranges Batholith, Baja California and Southern California: Geological Society of America Memoirs, v. 211, p. 263-316, http://dx.doi.org/10.1130/2014.1211 (07).

Kraemer, P.E., 2003, Orogenic shortening and the origin of the Patagonian orocline ( $56^{\circ}$ S.Lat): Journal of South American Earth Sciences, v.15, p. 731-748, http://dx.doi.org/ 10.1016/S0895-9811(02)00132-3.

LaPierre, H., Tardy, M., Coulon, C., Ortiz Hernandez, E., Bourdier, J.-L., Martínez Reyes, J., and Freydier, C., 1992, Caractérisation, genèse et évolution géodynamique du terrain de Guerrero (Mexique occidental): Canadian Journal of Earth Sciences, v. 29, p. 2478-2489, http://dx.doi.org/10.1139/e92-194.

Larson, K.P., Price, R.A., and Archibald, D.A., 2006, Tectonic implications of ${ }^{40} \mathrm{Ar} /{ }^{39} \mathrm{Ar}$ muscovite dates from the Mt. Haley stock and Lussier River stock, near Fort Steele, British Columbia: Canadian Journal of Earth Sciences, v. 43, p. 1673-1684, http://dx.doi.org/10.1139/e06-048.

Lawton, T.F., 2008, Laramide sedimentary basins, in Miall, A.D., ed., The Sedimentary Basins of the United States and Canada: Amsterdam: Sedimentary Basins of the World, v. 5, p. 429-450, http://dx.doi.org/10.1016/S18745997(08)00012-9.

Lawton, T.F., and McMillan, N.J., 1999, Arc abandonment as a cause for passive continental rifting: Comparison of the Jurassic Mexican Borderland rift and the Cenozoic Rio Grande rift: Geology, v. 27, p. 779-782,

http://dx.doi.org/10.1130/00917613(1999)027<0779:AAAACF > 2.3.C $\mathrm{O} ; 2$.

Lee, C-T.A., Morton, D.M., Kistler, R.W., and Baird, A.K., 2007, Petrology and tectonics of Phanerozoic continent formation: From island arcs to accretion and continental arc magmatism: Earth and Planetary Science Letters, v. 263, p. 370-387, http://dx.doi.org/ 10.1016/j.epsl.2007.09.025.

LeMaitre, R.W., ed., 1989, A Classification of Igneous Rocks and Glossary of Terms: Blackwell Scientific Publications, Oxford, 193 p.

Levi, B., and Aguirre, L., 1981, Ensialic spreading-subsidence in the Mesozoic and Palaeogene Andes of central Chile: Journal of the Geological Society, v. 138, p. 75-81, http://dx.doi.org/ 10.1144/gsigs.138.1.0075.

Loewy, S.L., Connelly, J.N., and Dalziel, I.W.D., 2004, An orphaned basement block: The Arequipa-Antofalla Basement of the central Andean margin of South America: Geological Society of America Bulletin, v. 116, p. 171-187, http://dx.doi.org/10.1130/B25226.1.

Macellari, C.E., Barrio, C.A., and Manassero, M.J., 1989, Upper Cretaceous to Paleocene depositional sequences and sandstone petrography of southwestern Patagonia (Argentina and Chile): Journal of South American Earth Sciences, v. 2, p. 223-239, http://dx.doi.org/10.1016/08959811(89)90031-X.

Maloney, K.T., Clarke, G.L., Klepeis, K.A., Fanning, C.M., and Wang, W., 2011, Crustal growth during back-arc closure: Cretaceous exhumation history of Cordillera Darwin, southern Patagonia: Journal of Metamorphic Geology, v. 29, p. 649-672, http://dx.doi.org/10.1111/j.15251314.2011.00934.x.

Martens, U.C., Brueckner, H.K., Mattinson, C.G., Liou, J.G., and Wooden, J.L., 2012, Timing of eclogite-facies metamorphism of the Chuacús complex, Central Guatemala: Record of Late Cretaceous continental subduction of North America's sialic basement: Lithos, v. 146-147, p. 1-10, http://dx.doi.org/10.1016/j.lithos.201 2.04.021.

Mathalone, J.M.P., and Montoya, M., 1995, Petroleum geology of the sub-Andean basins of Peru, in Tankard, A.J., Suárez Soruco, R., and Wolsink, H.J., eds., Petroleum Basins of South America: American Association of Petroleum Geologists, Memoir 62, p. 423-444.

Mattinson, J.M., 1978, Age, origin, and thermal histories of some plutonic rocks from the Salinian block of California: Contributions to Mineralogy and Petrology, v. 67, p. 233-245, http://dx.doi.org/10.1007/BF003814 51.

Mattinson, J.M., 1990, Petrogenesis and evolution of the Salinian magmatic arc, in Anderson, J.L., ed., The Nature and Origin of Cordilleran Magmatism:
Geological Society of America Memoirs, v. 174, p. 237-250, http://dx.doi.org/10.1130/MEM174p237.

Mattinson, J.M., Pessagno, E.A., Jr., Montgomery, H., and Hopson, C.A., 2008, Late Jurassic age of oceanic basement at La Désirade Island, Lesser Antilles arc, in Wright, J.E., and Shervais, J.W., eds., Ophiolites, Arcs, and Batholiths: A Tribute to Cliff Hopson: Geological Society of America Special Papers, v. 438, p. 175-190, http://dx.doi.org/ 10.1130/2008.2438(06).

Matzel, J.E.P., Bowring, S.A., and Miller, R.B., 2004, Protolith age of the Swakane Gneiss, North Cascades, Washington: Evidence of rapid underthrusting of sediments beneath an arc: Tectonics, v. 23, TC6009, http://dx.doi.org/10.1029/2003TC00 1577.

Mauel, D.J., Lawton, T.F., González-León, C., Iriondo, A., and Amato, J.M., 2011, Stratigraphy and age of Upper Jurassic strata in north-central Sonora, Mexico: Southwestern Laurentian record of crustal extension and tectonic transition: Geosphere, v. 7, p. 390-414, http://dx.doi.org/10.1130/ GES00600.1.

McCourt, W.J., 1981, The geochemistry and petrography of the Coastal Batholith of Peru, Lima segment: Journal of the Geological Society, v. 138, p. 407-420, http://dx.doi.org/ 10.1144/gsigs.138.4.0407.

McGrew, A.J., Peters, M.T., and Wright, J.E., 2000, Thermobarometric constraints on the tectonothermal evolution of the East Humboldt Range metamorphic core complex, Nevada: Geological Society of America Bulletin, v. 112 , p. 45-60, http://dx.doi.org/10.1130/00167606(2000)112<45:TCOTTE $>2.0$.CO ;2.

McKenzie, D.P., 1969, Speculations on the consequences and causes of plate motions: Geophysical Journal International, v. 18, p. 1-32, http://dx.doi.org/10.1111/j.1365246X.1969.tb00259.x.

McQuarrie, N., 2002, The kinematic history of the central Andean fold-thrust belt, Bolivia: Implications for building a high plateau: Geological Society of America Bulletin, v. 114, p. 950-963, http:/ /dx.doi.org/10.1130/00167606(2002)114<0950: TKHOTC>2.0. $\mathrm{CO} ; 2$.

McQuarrie, N., Horton, B.K., Zandt, G., Beck, S., and DeCelles, P.G., 2005, Lithospheric evolution of the Andean fold-thrust belt, Bolivia, and the ori- 
gin of the central Andean plateau:

Tectonophysics, v. 399, p. 15-37, http://dx.doi.org/10.1016/j.tecto.200 4.12.013

Mégard, F., 1984, The Andean orogenic period and its major structures in central and northern Peru: Journal of the Geological Society, v. 141, p. 893-900. http://dx.doi.org/10.1144/gsigs.141.5. 0893.

Mégard, F., 1987, Cordilleran Andes and Marginal Andes: A review of Andean geology north of the Arica elbow $\left(18^{\circ} \mathrm{S}\right)$, in Monger, J.W.H., and Francheteau, J., eds., Circum-Pacific Orogenic Belts and Evolution of the Pacific Ocean Basin: International Lithosphere Program Contribution, American Geophysical Union, Geodynamic Series, v. 18, p. 71-95, http://dx.doi.org/10.1029/GD018p0 071.

Memeti, V., Gehrels, G.E., Paterson, S.R., Thompson, J.M., Mueller, R.M., and Pignotta, G.S., 2010, Evaluating the Mojave-Snow Lake fault hypothesis and origins of central Sierran metasedimentary pendant strata using detrital zircon provenance analyses: Lithosphere, v. 2, p. 341-360, http://dx.doi.org/10.1130/L58.1.

Memeti, V., Paterson, S., and Mundil, R., 2012, Day 4: Magmatic evolution of the Tuolumne Intrusive Complex, in Formation of the Sierra Nevada Batholith: Magmatic and Tectonic Processes and Their Tempos: Geological Society of America Field Forum Field Trip Guide, p. 4-1-4-41.

Mišković, A., Spiking, R.A., Chew, D.M., Košler, J., Ulianov, A., and Schaltegger, U., 2009, Tectonomagmatic evolution of Western Amazonia: Geochemical characterization and zircon $\mathrm{U}-\mathrm{Pb}$ geochronologic constraints from the Peruvian Eastern Cordilleran granitoids: Geological Society of America Bulletin, v. 121, p. 1298-1324, http://dx.doi.org/10.1130/B26488.1.

Monod, O., Faure, M., and Salinas, J.-C., 1994, Intra-arc opening and closure of a marginal sea: The case of the Guerrero Terrane (SW Mexico): Island Arc, v. 3, p. 25-34, http://dx.doi.org/ 10.1111/j.1440-1738.1994.tb00002.x.

Montgomery, H., and Kerr, A.C., 2009, Rethinking the origin of the red chert at La Désirade, French West Indies, in James, K.H., Lorente, M.A., and Pindell, J.L., eds., The Origin and Evolution of the Caribbean Plate: Geological Society, London, Special Publications, v. 328, p. 457-467, http://dx.doi.org/10.1144/SP328.18.
Moore, J.G., Fleming, H.S., and Phillips, J.D., 1974, Preliminary model for extrusion and rifting at the axis of the Mid-Atlantic Ridge, $36^{\circ} 48^{\prime}$ North: Geology, v. 2, p. 437-440, http://dx.doi.org/10.1130/00917613(1974)2<437:PMFEAR>2.0.CO; 2.

Moore, T.E., Wallace, W.K., Mull, C.G., Adams, K.E., Plafker, G., and Nokleberg, W.J., 1997, Crustal implications of bedrock geology along the TransAlaska Crustal Transect (TACT) in the Brooks Range, northern Alaska: Journal of Geophysical Research, v. 102, p. 20645-20684, http://dx.doi.org/ 10.1029/96JB03733.

Moores, E., 1970, Ultramafics and orogeny, with models of the U.S. Cordillera and the Tethys: Nature, v. 228, p. 837-842, http://dx.doi.org/10.1038/228837a0.

Moores, E.M., 1982, Origin and emplacement of ophiolites: Reviews of Geophysics, v. 20 , p. $735-760$, http://dx.doi.org/10.1029/RG020i00 $4 \mathrm{p} 00735$.

Moores, E.M., and Twiss, R.J., 1995, Tectonics: W.H. Freeman, New York, 415 p.

Moores, E.M., Wakabayashi, J., and Unruh, J.R., 2002, Crustal-scale cross-section of the U.S. Cordillera, California and beyond, its tectonic significance, and speculations on the Andean Orogeny: International Geology Review, v. 44, p. 479-500, http://dx.doi.org/ 10.2747/0020-6814.44.6.479.

Moores, E.M., Wakabayashi, J., Unruh, J.R., and Waechther, S., 2006, A transect spanning 500 million years of active plate margin history: Outline and field trip guide, in Prentice, C.S., Scotchmoor, J.G., Moores, E.M., and Kiland, J.P., eds., 1906 San Francisco Earthquake GSA Field Guides: Geological Society of America Field Guides, v. 7, p. 373-413, http://dx.doi.org/ 10.1130/2006.1906SF(20).

Morabito, E.G., and Ramos, V.A., 2012, Andean evolution of the Aluminé fold and thrust belt, Northern Patagonian Andes (38 $30^{\prime}-40^{\circ} 30^{\prime}$ 'S): Journal of South American Earth Sciences, v. 38, p. 13-30, http://dx.doi.org/ 10.1016/j.jsames.2012.03.005.

Mosquera, A., and Ramos, V.A., 2006, Intraplate deformation in the Neuquén Embayment, in Kay, S.M., and Ramos, V.A., eds., Evolution of an Andean margin: A tectonic and magmatic view from the Andes to the Neuquén Basin ( $35^{\circ}-39^{\circ} \mathrm{S}$ lat): Geological Society of America Special Papers, v. 407, p. 97-123, http://dx.doi.org/10.1130/2006.2407
(05).

Mukasa, S.B., 1986, Zircon U-Pb ages of super-units in the Coastal batholith, Peru: Implications for magmatic and tectonic processes: Geological Society of America Bulletin, v. 97, p. 241-254, http://dx.doi.org/10.1130/00167606(1986) $97<241: Z U A O S I>2.0 . C O$; 2.

Müller, R.D., Royer, J.-Y., and Lawver, L.A., 1993, Revised plate motions relative to the hotspots from combined Atlantic and Indian Ocean hotspot tracks: Geology, v. 21, p. 275-278, http://dx.doi.org/10.1130/00917613(1993)021<0275:RPMRTT'>2.3.C $\mathrm{O} ; 2$.

Myers, J.S., 1974, Cretaceous stratigraphy and structure, western Andes of Peru, between latitudes $10^{\circ}-10^{\circ} 30^{\prime}$ : American Association of Petroleum Geologists Bulletin, v. 58, p. 474-487.

Myers, J. S., 1975, Vertical crustal movements of the Andes in Peru: Nature, v. 254 , p. $672-674$, http://dx.doi.org/10.1038/254672a0.

Nieto-Samaniego, A.F., Alaniz-Alvarez, S.A., Silva-Romo, G., Eguiza-Castro, M.H., and Mendoza-Rosales, C.C., 2006, Latest Cretaceous to Miocene deformation events in the eastern Sierra Madre del Sur, Mexico, inferred from the geometry and age of major structures: Geological Society of America Bulletin, v. 118, p. 238-252, http://dx.doi.org/10.1130/B25730.1.

Nokleberg, W.J., 1983, Wallrocks of the Central Sierra Nevada Batholith, California: A collage of accreted tectonostratigraphic terranes: U.S. Geological Survey Professional Paper 1255, 28 p.

Olivero, E.B., and Malumián, N., 2008, Mesozoic-Cenozoic stratigraphy of the Fuegian Andes, Argentina: Geologica Acta, v. 6, p. 5-18, http://dx.doi.org/10.1344/105.00000 238.

O’Neill, C., Müller, D., and Steinberger, B., 2005, On the uncertainties in hot spot reconstructions and the significance of moving hot spot reference frames: Geochemistry, Geophysics, Geosystems, v. 6, Q04003, http://dx.doi.org/ 10.1029/2004GC000784.

Ostos, M., Yoris, F., and Avé Lallemant, H.G., 2005, Overview of the southeast Caribbean-South American plate boundary zone, in Avé Lallemant, H.G., and Sisson, V.B., eds., Caribbean-South American Plate Interactions, Venezuela: Geological Society of America Special Papers, v. 394, p. 53-89, http://dx.doi.org/ 10.1130/0-8137-2394-9.53.

Page, B.M., 1970, Sur-Nacimiento fault 
zone of California: Continental margin tectonics: Geological Society of America Bulletin, v. 81, p. 667-690, http://dx.doi.org/10.1130/00167606(1970)81[667:SFZOCC]2.0.CO;2.

Page, B.M., 1982, Migration of Salinian composite block, California, and disappearance of fragments: American Journal of Science, v. 282, p. 1694-1734, http://dx.doi.org/ 10.2475/ajs.282.10.1694.

Paterson, S.R., Memeti, V., and Mundil, R., 2012a, Day 4: Magmatic evolution of the Tuolumne Intrusive Complex, in Formation of the Sierra Nevada Batholith: Magmatic and Tectonic Processes and Their Tempos: Geological Society of America Field Forum Field Trip Guide, p. 4.1-4.41.

Paterson, S.R., Memeti, V., Cao, W., Lackey, J.S., Putirka, K.D., Miller, R.B., Miller, J.S., and Mundil, R., 2012b, Day 6: Overview of arc processes and tempos, in Formation of the Sierra Nevada Batholith: Magmatic and Tectonic Processes and Their Tempos: Geological Society of America Field Forum Field Trip Guide, p. 6.1-6.34.

Peccerillo, A., and Taylor, S.R., 1976, Geochemistry of Eocene calc-alkaline volcanic rocks from the Kastamonu area, northern Turkey: Contributions to Mineralogy and Petrology, v. 58, p. 63-81, http://dx.doi.org/ 10.1007/BF00384745.

Pérez-Gutiérrez, R., Solari, L.A., GómezTuena, A., and Valencia, V.A., 2009, El terreno Cuicateco: ¿Cuenca oceánica con influencia de subducción del Cretácico Superior en el sur de México? Nuevos datos estructurales, geoquímicos y geocronológicos: Revista de la Mexicana de Ciencias Geológicas, v. 26, p. 222-242.

Peryam, T.C., Lawton, T.F., Amato, J.M., González-León, C.M., and Mauel, D.J., 2012, Lower Cretaceous strata of the Sonora Bisbee Basin: A record of the tectonomagmatic evolution of northwestern Mexico: Geological Society of America Bulletin, v. 124, p. 532-548, http://dx.doi.org/10.1130/B30456.1.

Petford, N., and Atherton, M.P., 1994, Cretaceous-Tertiary volcanism and synsubduction crustal extension in northern central Peru, in Smellie, J.L., ed., Volcanism Associated with Extension at Consuming Plate Margins: Geological Society, London, Special Publications, v. 81, p. 233-248, http://dx.doi.org/10.1144/GSL.SP.19 94.081.01.13.

Pfiffner, O.A., and Gonzalez, L., 2013, Mesozoic-Cenozoic evolution of the western margin of South America:
Case study of the Peruvian Andes:

Geosciences, v. 3, p. 262-310, http://dx.doi.org/10.3390/geosciences3020262.

Pindell, J.L., and Kennan, L., 2009, Tectonic evolution of the Gulf of Mexico, Caribbean and northern South Ameri$\mathrm{ca}$ in the mantle reference frame: An update, in James, K.H., Lorente, M.A., and Pindell, J.L., eds., The Origin and Evolution of the Caribbean Plate: Geological Society, London, Special Publications, v. 328, p. 1-55, http://dx.doi.org/10.1144/SP328.1.

Pindell, J.L., Kennan, L., Maresch, W.V., Stanek, K.-P., Draper, G., and Higgs, R., 2005, Plate-kinematics and crustal dynamics of circum-Caribbean arccontinent interactions: Tectonic controls on basin development in ProtoCaribbean margins, in Avé Lallemant, H.G., and Sisson, V.B., eds., Caribbean-South American Plate Interactions, Venezuela: Geological Society of America Special Papers, v. 394, p. 7-52, http://dx.doi.org/ 10.1130/0-8137-2394-9.7.

Pitcher, W.S., 1978, The anatomy of a batholith: President's anniversary address 1977: Journal of the Geological Society, v. 135, p. 157-182, http://dx.doi.org/10.1144/gsjgs.135.2. 0157.

Pitcher, W.S., 1985, A multiple and composite batholith, in Pitcher, W.S., Atherton, M.P., Cobbing, E.J., and Beckinsale, R.B., eds., Magmatism at a Plate Edge: the Peruvian Andes: Blackie Halstead Press, Glasgow, p. 93-107, http://dx.doi.org/ 10.1007/978-1-4899-5820-4_9.

Pitcher, W.S., 1993, The Nature and Origin of Granite: London, Blackie Academic, 321 p., http://dx.doi.org/ 10.1007/978-94-017-3393-9.

Pitcher, W.S., and Bussell, A., 1985, Andean dike swarms: Andesite in synplutonic relationship with tonalite, in Pitcher, W.S., Atherton, M.P., Cobbing, E.J., and Beckinsale, R.B., eds., Magmatism at a Plate Edge: the Peruvian Andes: Blackie Halstead Press, Glasgow, p. 102-107, http:/ /dx.doi.org/10.1007/978-14899-5820-4_10.

Pitcher, W.S., Atherton, M.P., Cobbing, E.J., and Beckinsdale, R.D., 1985, Magmatism at a Plate Edge: the Peruvian Andes: Blackie Halsted Press, Glasgow, 328 p., http://dx.doi.org/ 10.1007/978-1-4899-5820-4.

Polliand, M., Schaltegger, U., Frank, M., and Fontboté, L., 2005, Formation of intra-arc volcanosedimentary basins in the western flank of the central Peru- vian Andes during Late Cretaceous oblique subduction: field evidence and constraints from U-Pb ages and Hf isotopes: International Journal of Earth Sciences, v. 94, p. 231-242, http://dx.doi.org/10.1007/s00531005-0464-5.

Powell, R.E., 1993, Balanced palinspastic reconstruction of pre-late Cenozoic paleogeology, southern California: Geologic and kinematic constraints on evolution of the San Andreas fault system, in Powell, R.E., Weldon, R.J., II, and Matti, J.C., eds., The San Andreas Fault System: Displacement, Palinspastic Reconstruction, and Geologic Evolution: Geological Society of America Memoirs, v. 178, p. 1-106, http://dx.doi.org/10.1130/MEM178.

Premo, W.R., Poole, F.G., and AmayaMartínez, R., 2010, Provenance of detrital zircons in Ordovician Iapetus ocean-basin quartzites in Sonora, Mexico (abstract): Geological Society of America, Abstracts with Programs, v. 42 , p. 427.

Premo, W.R., Morton, D.M., Wooden, J.L., and Fanning, C.M., 2014, U-Pb zircon geochronology of plutonism in the northern Peninsular Ranges batholith, southern California: Implications for the Late Cretaceous tectonic evolution of southern California, in Morton, D.M., and Miller, F.K., eds., Peninsular Ranges Batholith, Baja California and Southern California: Geological Society of America Memoirs, v. 211, p. 145-180, http:/ /dx.doi.org/ 10.1130/2014.1211(04).

Price, N.J., and Audley-Charles, M.G., 1987, Tectonic collision after plate rupture: Tectonophysics, v. 140, p. 121-129, http://dx.doi.org/10.1016/00401951(87)90224-1.

Price, R.A., 1981, The Cordilleran foreland thrust and fold belt in the southern Canadian Rocky Mountains, in McClay, K.R., and Price, N.J., eds., Thrust and Nappe Tectonics: Geological Society, London, Special Publications, v. 9, p. 427-448,

http://dx.doi.org/10.1144/GSL.SP.19 81.009.01.39.

Price, R.A., and Fermor, P.R., 1985, Structure section of the Cordilleran foreland thrust and fold belt west of Calgary, Alberta: Geological Survey of Canada Paper 84-14, 1 sheet.

Price, R.A., and Mountjoy, E.W., 1970, Geologic structure of the Canadian Rocky Mountains between Bow and Athabasca Rivers: A progress report, in Wheeler, J.O., ed., Structure of the Southern Canadian Cordillera: Geological Association of Canada Special 
Publication 6, p. 7-25.

Pugh, P.J.A., and Convey, P., 2000, Scotia Arc Acari: Antiquity and origin: Zoological Journal of the Linnean Society, v. 130 , p. 309-328, http://dx.doi.org/ 10.1111/j.1096-3642.2000.tb01633.x.

Ramos, V.A., 2008, The basement of the central Andes: The Arequipa and related terranes: Annual Review of Earth and Planetary Sciences, v. 36, p. 289-324, http://dx.doi.org/

10.1146/annurev.earth.36.031207.1243 04.

Ramos, V.A., 2009, Anatomy and global context of the Andes: Main geologic features and the Andean orogenic cycle, in Kay, S.M., Ramos, V.A., and Dickinson, W.R., eds., Backbone of the Americas: Shallow Subduction, Plateau Uplift, and Ridge and Terrane Collision: Geological Society of America Memoirs, v. 204, p. 31-65, http://dx.doi.org/10.1130/2009.1204( 02).

Ramos, V.A., 2010a, The tectonic regime along the Andes: Present-day and Mesozoic regimes: Geological Journal, v. 45 , p. $2-25$, http://dx.doi.org/10.1002/gj.1193.

Ramos, V.A., 2010b, The Grenville-age basement of the Andes: Journal of South American Earth Sciences, v. 29, p. 77-91, http://dx.doi.org/ 10.1016/j.jsames.2009.09.004.

Ramos, V.A., and Folguera, A., 2005, Tectonic evolution of the Andes of Neuquén: Constraints derived from the magmatic arc and foreland deformation, in Veiga, G.D., Spalletti, L.A., Howell, J.A., and Schwartz, E., eds., The Neuquén Basin, Argentina: A case study in sequence stratigraphy and basin dynamics: Geological Society, London, Special Publications, v. 252, p. 15-37, http://dx.doi.org/ 10.1144/GSL.SP.2005.252.01.02.

Ramos, V.A., and Kay, S.M., 2006, Overview of the tectonic evolution of the southern Central Andes of Mendoza and Neuquén $\left(35^{\circ}-39^{\circ} \mathrm{S}\right.$ latitude), in Kay, S.M., and Ramos, V.A., eds., Evolution of an Andean margin: A tectonic and magmatic view from the Andes to the Neuquén Basin

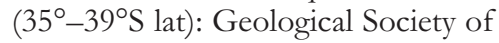
America Special Papers, v. 407, p. 1-17, http:/ /dx.doi.org/ 10.1130/2006.2407(01).

Ramos, V.A., Zapata, T., Cristillini, E., and Introcaso, A., 2004, The Andean thrust system - Latitudinal variations in structural styles and orogenic shortening, in McClay, K.R., ed., Thrust tectonics and hydrocarbon systems: American Association of Petroleum
Geologists Memoir 82, p. 30-50.

Ratschbacher, L., Franz, L., Min, M., Bachmann, R., Martens, U., Stanek, K., Stübner, K., Nelson, B.K., Herrmann, U., Weber, B., López-Martínez, M., Jonckheere, R., Sperner, B., Tichomirowa, M., McWilliams, M.O., Gordon, M., Meschede, M., and Bock, P., 2009, The North AmericanCaribbean plate boundary in MexicoGuatemala-Honduras, in James, K.H., Lorente, M.A., and Pindell, J.L., eds., The Origin and Evolution of the Caribbean Plate: Geological Society, London, Special Publications, v. 328, p. 219-293, http://dx.doi.org/10.1144/SP328.11.

Regan, P.F., 1985, The early basic intrusions, in Pitcher, W.S., Atherton, M.P., Cobbing, E.J., and Beckinsale, R.B., eds., Magmatism at a Plate Edge: the Peruvian Andes: Blackie Halstead Press, Glasgow, p. 72-89, http://dx.doi.org/10.1007/978-14899-5820-4_8.

Ridgway, K.D., Trop, J.M., Nokleberg, W.J., Davidson, C.M., and Eastham, K.R., 2002, Mesozoic and Cenozoic tectonics of the eastern and central Alaska Range: Progressive basin development and deformation in a suture zone: Geological Society of America Bulletin, v. 114, p. 1480-1504, http:/ /dx.doi.org/10.1130/0016 7606(2002)114<1480:MACTOT> 2.0.CO;2.

Roeder, D.H., 1973, Subduction and orogeny: Journal of Geophysical Research, v. 78 , p. $5005-5024$, http://dx.doi.org/10.1029/JB078i023 p05005.

Rogers, R.D., Mann, P., Emmet, P.A., and Venable, M.E., 2007, Colon fold belt of Honduras: Evidence for Late Cretaceous collision between the continental Chortis block and intra-oceanic Caribbean arc, in Mann, P., ed., Geologic and Tectonic Development of the Caribbean Plate in Northern Central America: Geological Society of America Special Papers, v. 428, p. 129-149, http:/ /dx.doi.org/ 10.1130/2007.2428(06).

Romero, D., Valencia, K., Alarcón, P., Peña, D., and Ramos, V.A., 2013, The offshore basement of Perú: Evidence for different igneous and metamorphic domains in the forearc: Journal of South American Earth Sciences, v. 42, p. 47-60, http://dx.doi.org/ 10.1016/j.jsames.2012.11.003.

Ross, D.C., 1977, Pre-intrusive metasedimentary rocks of the Salinian block, California - A paleotectonic dilemma, in Stewart, J.H., Stevens, C.H., and
Fritsche, A.E., eds., Paleozoic Paleogeography of the Western United States: Society of Economic Paleontologists and Mineralogists, Pacific Section, Pacific Coast Paleogeography Symposium 1, p. 371-380.

Ross, D.C., 1978, The Salinian block-A Mesozoic granitic orphan in the California Coast Ranges, in Howell, D.G., and McDougall, K.A., eds., Mesozoic Paleogeography of the Western United States: Society of Economic Paleontologists and Mineralogists, Pacific Section, Pacific Coast Paleogeography Symposium 2, p. 509-522.

Ross, G.M., Patchett, P.J., Hamilton, M., Heaman, L., DeCelles, P.G., Rosenberg, E., and Giovanni, M.K., 2005, Evolution of the Cordilleran orogen (southwestern Alberta, Canada) inferred from detrital mineral geochronology, geochemistry, and $\mathrm{Nd}$ isotopes in the foreland basin: Geological Society of America Bulletin, v. 117 , p. $747-763$, http://dx.doi.org/10.1130/ B25564.1.

Sacks, P.E., and Secor, D.T., 1990, Delamination in collisional orogens: Geology, v. 18, p. 999-1002, http://dx.doi.org/ 10.1130/0091-7613(1990)018 $<0999$ :DICO>2.3.CO;2.

Saleeby, J.B., Ducea, M.N., Busby, C.J., Nadin, E.S., and Wetmore, P.H., 2008, Chronology of pluton emplacement and regional deformation in the southern Sierra Nevada batholith, California, in Wright, J.E., and Shervais, J.W., eds., Ophiolites, Arcs, and Batholiths: A Tribute to Cliff Hopson: Geological Society of America Special Papers, v. 438, p. 397-427, http://dx.doi.org/10.1130/2008.2438 (14).

Schenk, C.J., Viger, R.J., and Anderson, C.P., 1997, Maps showing geology, oil and gas fields, and geologic provinces of South America: United States Geological Survey, Open File 97-470D, 12 p.

Scherrenberg, A.F., Jacay, J., Holcombe, R.J., and Rosenbaum, G., 2012, Stratigraphic variations across the Marañón Fold-Thrust Belt, Peru: Implications for the basin architecture of the West Peruvian Trough: Journal of South American Earth Sciences, v. 38, p. 147-158, http:/ /dx.doi.org/ 10.1016/j.jsames.2012.06.006.

Scherrenberg, A.F., Holcombe, R.J., and Rosenbaum, G., 2014, The persistence and role of basin structures on the 3D architecture of the Marañón FoldThrust Belt, Peru: Journal of South American Earth Sciences, v. 51, p. 45-58, http://dx.doi.org/ 
10.1016/j.jsames.2013.12.007.

Schrecengost, K.L., 2010, Geochemistry and $\mathrm{U} / \mathrm{Pb}$ zircon geochronology of the Virgin Islands batholith, British Virgin Islands: Unpublished MSc thesis, University of North Carolina, Chapel Hill, NC, 73 p.

Sempere, T., Butler, R.F., Richards, D.R., Marshall, L.G., Sharp, W., and Swisher, C.C., III, 1997, Stratigraphy and chronology of Upper Cretaceouslower Paleogene strata in Bolivia and northwest Argentina: Geological Society of America Bulletin, v. 109, p. 709-727, http://dx.doi.org/ 10.1130/0016-7606(1997)109 $<0709$ :SACOUC $>2.3$.CO;2.

Seton, M., Müller, R.D., Zahirovic, S., Gaina, C., Torsvik, T., Shephard, G., Talsma, A., Gurnis, M., Turner, M., Maus, S., and Chandler, M., 2012, Global continental and ocean basin reconstructions since 200 Ma: EarthScience Reviews, v. 113, p. 212-270, http://dx.doi.org/10.1016/j.earscirev. 2012.03.002.

Shackleton, R.M., Ries, A.C., Coward, M.P., and Cobbold, P.R., 1979, Structure, metamorphism and geochronology of the Arequipa massif of Coastal Peru: Journal of the Geological Society, v. 136, p. 195-214, http://dx.doi.org/ 10.1144/gsigs.136.2.0195.

Shaw, S.E., Todd, V.R., Kimbrough, D.L., and Pearson, N.J., 2014, A west-to-east geologic transect across the Peninsular Ranges batholith, San Diego County, California: Zircon ${ }^{176} \mathrm{Hf} /{ }^{177} \mathrm{Hf}$ evidence for the mixing of crustal- and mantlederived magmas, and comparisons with the Sierra Nevada batholith, in Morton, D.M., and Miller, F.K., eds., Peninsular Ranges Batholith, Baja California and Southern California: Geological Society of America Memoirs, v. 211, p. 499-536, http://dx.doi.org/ 10.1130/2014.1211 (15).

Shephard, G.E., Bunge, H.-P., Schuberth, B.S.A., Müller, R.D., Talsma, A.S., Moder, C., and Landgrebe, T.C.W., 2012, Testing absolute plate reference frames and the implications for the generation of geodynamic mantle heterogeneity structure: Earth and Planetary Science Letters, v. 317-318, p. 204-217, http://dx.doi.org/ 10.1016/j.epsl.2011.11.027.

Sigloch, K., 2011, Mantle provinces under North America from multifrequency $P$ wave tomography: Geochemistry, Geophysics. Geosystems, v. 12, Q02W08, http://dx.doi.org/ 10.1029/2010GC003421.

Sigloch, K., and Mihalynuk, M.G., 2013, Intra-oceanic subduction shaped the assembly of Cordilleran North America: Nature Geoscience, v. 496, p. 50-56, http://dx.doi.org/ 10.1038/nature12019.

Silver, L.T., and Chappell, B.W., 1988, The Peninsular Ranges Batholith: An insight into the evolution of the Cordilleran batholiths of southwestern North America: Transactions of the Royal Society of Edinburgh: Earth Sciences, v. 79, p. 105-121, http://dx.doi.org/10.1017/S02635933 00014152.

Solomon, M., 1990, Subduction, arc reversal, and the origin of porphyry copper-gold deposits in island arcs: Geology, v. 18, p. 630-633,

http://dx.doi.org/10 .1130/00917613(1990)018<0630:SARATO > 2.3.C $\mathrm{O} ; 2$.

Spagnuolo, M.G., Folguera, A., Litvak, V., Rojas Vera, E.A., and Ramos, V.A., 2012, Late Cretaceous arc rocks in the Andean retroarc region at $36.5^{\circ} \mathrm{S}$ : Evidence supporting a Late Cretaceous slab shallowing: Journal of South American Earth Sciences, v. 38, p. 44-56, http://dx.doi.org/ 10.1016/j.jsames.2012.05.002.

Stewart, J.H., 2005, Evidence for MojaveSonora megashear-Systematic leftlateral offset of Neoproterozoic to Lower Jurassic strata and facies, western United States and northwestern Mexico, in Anderson, T.H., Nourse, J.A., McKee, J.W., and Steiner, M.B., eds., The Mojave-Sonora Megashear Hypothesis: Development, Assessment, and Alternatives: Geological Society of America Special Papers, v. 393, p. 209-231, http://dx.doi.org/ 10.1130/2005.2393(05).

Streckeisen, A.L., and Le Maitre, R.W., 1979, A chemical approximation to the modal QAPF classification of the igneous rocks: Neues Jahrbuch für Mineralogie, Abhandlungen, v. 136, p.169-206.

Suárez, M., de la Cruz, R., and Bell, C.M., 2000, Timing and origin of deformation along the Patagonian fold and thrust belt: Geological Magazine, v. 137, p. 345-353, http://dx.doi.org/ 10.1017/S0016756800004192.

Sun, S.-s., and McDonough, W.F., 1989, Chemical and isotopic systematics of oceanic basalt: implications for mantle composition and processes, in Saunders, A.D., Norry, M.J, eds., Magmatism in the Ocean Basins: Geological Society, London, Special Publications, v. 42, 313-345, http://dx.doi.org/ 10.1144/GSL.SP.1989.042.01.19.

Suter, M., 1984, Cordilleran deformation along the eastern edge of the
Valles-San Luis Potosí carbonate platform, Sierra Madre Oriental foldthrust belt, east-central Mexico: Geological Society of America Bulletin, v. 95, p. 1387-1397,

http://dx.doi.org/10.1130/00167606(1984)95<1387:CDATEE $>2.0$ .CO;2.

Suter, M., 1987, Structural traverse across the Sierra Madre Oriental fold-thrust belt in east-central Mexico: Geological Society of America Bulletin, v. 98, p. 249-264, http:/ /dx.doi.org/ 10.1130/0016-7606(1987)98 $<249$ :STATSM>2.0.CO;2.

Tardy, M., Lapierre, H., Freydier, C., Coulon, C., Gill, J.-B., Mercier de Lepinay, B., Beck, C., Martinez R., J., Talavera M., O., Ortiz H., E., Stein, G., Bourdier, J.-L., and Yta, M., 1994, The Guerrero suspect terrane (western Mexico) and coeval arc terranes (the Greater Antilles and the Western Cordillera of Colombia): A late Mesozoic intra-oceanic arc accreted to cratonal America during the Cretaceous: Tectonophysics, v. 230, p. 49-73, http://dx.doi.org/10.1016/00401951(94)90146-5.

Tassinari, C.C.G., Castroviejo, R., Rodrigues, J.F., Acosta, J., and Pereira, E., 2011, A Neoproterozoic age for the chromitite and gabbro of the Tapo ultramafic Massif, Eastern Cordillera, Central Peru and its tectonic implications: Journal of South American Earth Sciences, v. 32, p. 429-437, http:/ /dx.doi.org/ 10.1016/j.jsames.2011.03.008.

Thornburg, T., and Kulm, L.D., 1981, Sedimentary basins of the Peru continental margin: Structure, stratigraphy and Cenozoic tectonics from $6^{\circ} \mathrm{S}$ to $16^{\circ} \mathrm{S}$ latitude, in Jones, P.R., III, ed., Crustal structures of the Peru continental margin and adjacent Nazca plate, $9^{\circ} \mathrm{S}$ latitude: Geological Society of America Memoirs, v. 154, p. 393-422, http://dx.doi.org/10.1130/MEM154p393.

Torsvik, T.H., Müller, R.D., van der Voo, R., Steinberger, B., and Gaina, C., 2008a, Global plate motion frames: Toward a unified model: Reviews of Geophysics, v. 46, RG3004, http:/ / dx.doi.org/10.1029/2007RG000227.

Torsvik, T.H., Steinberger, B., Cocks, L.R.M., and Burke, K., 2008b, Longitude: Linking Earth's ancient surface to its deep interior: Earth and Planetary Science Letters, v. 276, p. 273-282, http://dx.doi.org/ 10.1016/j.epsl.2008.09.026.

Trønnes, R.G., 2010, Structure, mineralogy and dynamics of the lowermost man- 
tle: Mineralogy and Petrology, v. 99, p. 243-261, http://dx.doi.org/ 10.1007/s00710-009-0068-z.

Trop, J.M., and Ridgway, K.D., 2007, Mesozoic and Cenozoic tectonic growth of southern Alaska: A sedimentary basin perspective, in Ridgway, K.D., Trop, J.M., Glen, J.M.G., and O’Neill, J.M., eds., Tectonic Growth of a Collisional Continental Margin: Crustal Evolution of South-Central Alaska: Geological Society of America Special Papers, v. 431, p. 55-94.

Vaughan, A.P.M., Leat, P.T., and Pankhurst, R.J., 2005, Terrane processes at the margins of Gondwana: introduction, in Vaughan, A.P.M., Leat, P.T., and Pankhurst, R.J., eds., Terrane Processes at the Margins of Gondwana: Geological Society, London, Special Publications, v. 246, p. 1-21, http://dx.doi.org/10.1144/GSL.SP.20 05.246.01.01.

Villagómez, D., and Spikings, R., 2013, Thermochronology and tectonics of the central and western Cordilleras of Columbia: Early Cretaceous-Tertiary evolution of the northern Andes: Lithos, v. 160-161, p. 228-249, http://dx.doi.org/10.1016/j.lithos.201 2.12.008.

von Huene, R., and Ranero, C.R., 2009, Neogene collision and deformation of convergent margins along the backbone of the Americas, in Kay, S.M., Ramos, V.A., and Dickinson, W.R., eds., Backbone of the Americas: Shallow Subduction, Plateau Uplift, and Ridge and Terrane Collision: Geological Society of America Memoirs, v. 204, p. 67-83, http://dx.doi.org/ 10.1130/2009.1204(03).

Walawender, M.J., Gastil, R.G., Clinkenbeard, J.P., McCormick, W.V., Eastman, B.G., Wernicke, R.S., Wardlaw, M.S., Gunn, S.H., and Smith, B.M., 1990 , Origin and evolution of the zoned La Posta-type plutons, eastern Peninsular Ranges batholith, southern and Baja California, in Anderson, J.L., ed., The Nature and Origin of Cordilleran Magmatism: Geological Society of America Memoirs, v. 174, p. 1-18, http://dx.doi.org/ 10.1130/MEM174-p1.

Wang Qiang, Wyman, D.A., Xu Jifeng, Jian Ping, Zhao Zhenhua, Li Chaofeng, Xu Wei, Ma Jinlong, He Bin, 2007, Early Cretaceous adakitic granites in the Northern Dabie Complex, central China: Implications for partial melting of thickened lower crust: Geochimica et Cosmochimica Acta, v. 71, p. 2609-2636, http://dx.doi.org/ 10.1016/j.gca.2007.03.008.
Watson, E.B., and Harrison, T.M., 1983, Zircon saturation revisited: temperature and composition effects in a variety of crustal magma types: Earth and Planetary Science Letters, v. 64, p. 295-304, http:/ /dx.doi.org/ 10.1016/0012-821X(83)90211-X.

Wetmore, P.H., Alsleben, H., Paterson, S.R., Ducea, M., Gehrels, G., and Valencia, V., 2005, Field trip to the northern Alisitos arc segment: Ancestral Agua Blanca fault region: Field trip guide for the VII International Meeting of the Peninsular Geological Society, $40 \mathrm{p}$.

Whalen, J.B., and Frost, C.D., 2013, The QANOR diagram: A tool for the petrogenetic and tectonomagmatic characterization of granitic suites (abstract): Geological Society of America Abstracts with Programs. v. 45, no. 3, p.24.

Whalen, J.B., McNicoll, V.J., van Staal, C.R., Lissenberg, C.J., Longstaffe, F.J., Jenner, G.A., and van Breeman, O., 2006, Spatial, temporal and geochemical characteristics of Silurian collisionzone magmatism, Newfoundland Appalachians: An example of a rapidly evolving magmatic system related to slab break-off: Lithos, v. 89, p. 377-404, http:/ /dx.doi.org/ 10.1016/j.lithos.2005.12.011.

Whidden, K.J., Lund, S.P., Bottjer, D.J., Champion, D., and Howell, D.G., 1998, Paleomagnetic evidence that the central block of Salinia is not a fartraveled terrane: Tectonics, v. 17, p. 329-343, http:/ /dx.doi.org/ 10.1029/97TC03021.

Williams, M.L., Fischer, K.M., Freymueller, J.Y., Tikoff, B., Tréhu, A.M., and others, 2010, Unlocking the Secrets of the North American Continent: An EarthScope Science Plan for 2010-2020, 78 p.

Willner, A., Castroviejo, R., Rodrigues, J.F., Acosta, J., and Rivera, M., 2010, High pressure metamorphic conditions in garnet amphibolite from a collisional shear zone related to the Tapo ultramafic body, Eastern Cordillera of Central Peru: XV Congreso Peruano de Geología, Cusco, Sociedad Geológica del Perú, Publicacíon especial 9, p. 87-90.

Wilson, J.J., 1963, Cretaceous stratigraphy of central Andes of Peru: Bulletin of the American Association of Petroleum Geologists, v. 47, p. 1-34.

Wilson, J.J., Reyes Rivera, L., and Garayar, S.J., 1967, Geologia de los cuadrangolos de Mollebamba, Tayabamba, Huaylas, Pomabamba Carhuaz y Huari: Servicio de Geologia y Minera,
Boletin 16, $95 \mathrm{p}$.

Wilson, P.A., 1975, K-Ar age studies in Peru with special reference to the emplacement of the Coastal batholith: Unpublished $\mathrm{PhD}$ thesis, University of Liverpool, Liverpool, England, 299 p.

Wilson, T.J., 1991, Transition from backarc to foreland basin development in the southernmost Andes: Stratigraphic record from the Ultima Esperanza District, Chile: Geological Society of America Bulletin, v. 103, p. 98-111, http://dx.doi.org/10.1130/00167606(1991)103<0098:TFBATF>2.3.C $\mathrm{O} ; 2$.

Winter, L.S., 2008, The genesis of "giant" copper-zinc-gold-silver volcanogenic massive sulphide deposits at Tambogrande, Peru: Age, tectonic setting, paleomorphology, lithogeochemistry and radiogenic isotopes: Unpublished $\mathrm{PhD}$ thesis, University of British Columbia, Vancouver, Canada, 260 p.

Winter, L.S., Tosdal, R.M., Mortensen, J.K., and Franklin, J.M., 2010, Volcanic stratigraphy and geochronology of the Cretaceous Lancones Basin, Northwestern Peru: Position and timing of Giant VMS Deposits: Economic Geology, v. 105, p. 713-742, http://dx.doi.org/10.2113/gsecongeo.105.4.713

Yonkee, W.A., and Weil, A.B., 2011, Evolution of the Wyoming salient of the Sevier fold-thrust belt, northern Utah to western Wyoming, in Sprinkel, D.A., Yonkee, W.A., and Chidsey, T.C., Jr., eds., Sevier Thrust Belt: Northern and Central Utah and Adjacent Areas: Utah Geological Association Publication 40, p. 1-56.

Zapata, T., and Folguera, A., 2006, Tectonic evolution of the Andean fold and thrust belt of the southern Neuquén Basin, Argentina, in Veiga, G.D., Spalletti, L.A., Howell, J., and Schwarz, E., eds., The Neuquén Basin, Argentina: A case study in sequence stratigraphy and basin dynamics: Geological Society, London, Special Publications, v. 252, p. 37-56, http://dx.doi.org/ 10.1144/GSL.SP.2005.252.01.03.

Received July 2014

First published on the web July 2014 